\title{
Evolution of a Paleoproterozoic "weak type" orogeny in the West African Craton (Ivory Coast)
}

\author{
M. Vidal ${ }^{\mathrm{a}}$, C. Gumiaux ${ }^{\mathrm{a}, \text {, F. Cagnard }}{ }^{\mathrm{b}}$, A. Pouclet ${ }^{\mathrm{a}}$, G. Ouattara ${ }^{\mathrm{c}}$ and M. Pichon $^{\mathrm{a}}$ \\ ${ }^{a}$ ISTO, UMR6113 CNRS/Univ. Orléans, 1a rue de la Férollerie, 45071 Orléans Cedex2, \\ France \\ ${ }^{\text {b} B R G M, ~} 3$ av. Claude Guillemin, BP 36009, 45060 Orléans Cedex2, France \\ ${ }^{\mathrm{c} E N S T P, ~ Y a m o u s s o u k r o, ~ A b i d j a n, ~ C o ̂ t e ~ d ' I v o i r e, ~ F r a n c e ~}$
}

\begin{abstract}
The Paleoproterozoic domain of the Ivory Coast lies in the central part of the West African Craton (WAC) and is mainly constituted by TTG, greenstones, supracrustal rocks and leucogranites. A compilation of metamorphic and radiometric data highlights that: i) metamorphic conditions are rather homogeneous through the domain, without important metamorphic jumps, ii) HP-LT assemblages are absent and iii) important volumes of magmas emplaced during the overall Paleoproterozoic orogeny suggesting the occurrence of longlived rather hot geotherms. Results of the structural analysis, focused on three areas within the Ivory Coast, suggest that the deformation is homogeneous and distributed through the Paleoproterozoic domain. In details, results of this study point out the long-lived character of vertical movements during the Eburnean orogeny with a two folds evolution. The first stage is characterized by the development of "domes and basins" geometries without any boundary tectonic forces and the second stage is marked by coeval diapiric movements and horizontal regional-scale shortening. These features suggest that the crust is affected by vertical movements during the overall orogeny. The Eburnean orogen can then be considered as an example of long-lived Paleoproterozoic “weak-type” orogen.
\end{abstract}

Keywords: Paleoproterozoic; Birimian; Weak orogeny; Homogeneous strain; Domes and basins; West African Craton; Ivory Coast

\section{Introduction}

Several studies point out the existence of "archaic" mechanisms of deformation during juvenile crust formation, i.e. homogeneous deformation marked by vertical crustal movements with combined burial and diapirism mechanisms into the crust (e.g. [Delor et al., 1991], [Pons et al., 1992], [Bouhallier et al., 1995], [Chardon et al., 1996], [Chardon et al., 1998], [Chardon et al., 2002] and [Van Kranendonk et al., 2004]). Most of these studies focused on Archean orogens where "domes and basins" development is related to the sagduction of dense supracrustal rocks and to the uprise of relatively lighter underlying crust (e.g. [Gorman et al., 1978], [Bouhallier et al., 1995], [Chardon et al., 1996] and [Chardon et al., 2002]).

Nevertheless, such archaic-type deformation mode, implying vertical movements and distributed strain, appears to be dependent on the rheology profile within the continental lithosphere and can develop within weak crust which does not necessarily display inverse density gradients ([Cagnard et al., 2006a], [Cagnard et al., 2006b], [Cagnard et al., 2007] and [Gapais et al., 2008]). However, the application of the "archaic" model of evolution for domains younger than Archean, and in particular for Paleoproterozoic once, is still debated. 
The Paleoproterozoic domain (2.3 to $1.8 \mathrm{Ga}$ ), forms a consequent part of the West African Craton (WAC). It consists in a Paleoproterozoic juvenile continental crust which has been created during the Eburnean orogenic event, most likely from oceanic material ([Abouchami et al., 1990], [Boher et al., 1992], [Dia et al., 1997] and [Pouclet et al., 2006]), with only limited and localised inheritance of older Archean crustal rocks ([Kouamelan et al., 1997a] and [Kouamelan et al., 1997b]). This domain has remained a stable craton from that time, without any subsequent reworking of the Eburnean structures. Different models have already been proposed for explaining the Eburnean orogeny in west Africa, from: i) a "modern-type" orogenic belt evolution, with the development of major thrusts ([Milési et al., 1989], [Ledru et al., 1990], [Feybesse and Milési, 1994] and [Billa et al., 1999]) to ii) more "archaic" type models which highlight, in particular, the role of the diapirism during the Eburnean orogeny ([Vidal, 1987], [Vidal et al., 1996], [Boher et al., 1992], [Hirdes et al., 1992], [Nikiéma et al., 1993], [Delor et al., 1995a], [Pons et al., 1995] and [Pouclet et al., 1996]).

This paper presents a compilation of cartographic data from the last 1/200,000 mapping projects hold through Ivory Coast ([Delor et al., 1995b], [Koné et al., 1995], [Siméon et al. 1995a] and [Zéade et al., 1995]) as well as new structural data coming from previous unpublished field works ([Doumbia, 1997] and [Ouattara, 1998]). This work focuses on three principal zones dividing the central part of the Paleoproterozoic domain of the WAC through the Ivory Coast in order to characterise regional-scale deformations across the Eburnean orogen. It shows a deformation pattern suggesting homogeneous, pervasive deformation of a weak crust during overall orogeny. This study highlights how vertical, "archaic-type" mechanisms of deformation can have been important during the Birimian, which is a key period to understand the evolution of the mechanical behaviour of the continental lithosphere over times.

\section{Geological setting}

The Paleoproterozoic domain of West Africa is located between the Archean craton of Man, to the west, and the Volta basin, to the east (Fig. 1). Within this domain, the outcropping rocks are dated in-between 2.2 and $2.0 \mathrm{Ga}$ (e.g. [Kouamelan et al., 1997a], [Kouamelan et al., 1997b], [Doumbia et al., 1998], [Caen-Vachette, 1986], [Hirdes et al., 1992], [Hirdes et al., 1996], [Hirdes and Davis, 2002] and [Oberthür et al., 1998]; Lüdtke et al., 1999; [Castaing et al., 2003], [Gasquet et al., 2003] and [Castaing et al., 2004];). They consist of: i) early Tonalite-Trondjhemite-Granodiorite (TTG) and tholeitic greenstone complexes ( 2.2 to $2.15 \mathrm{Ga}$ ), ii) low metamorphic grade volcano-sedimentary series made of clastic sediments intercalated with calc-alkaline volcanic levels $(\sim 2.15 \mathrm{Ga})$ and iii) leucogranites $(\sim 2.1 \mathrm{Ga}$; Fig. 1 and Fig. 2a). Geochemical and isotopic studies have shown that a large part of this Paleoproterozoic domain, in Ivory Coast, Burkina-Faso and Niger, was a juvenile crust, i.e. entirely created during Paleoproterozoic times; the only traces of inheritance of Archean rocks have been found along the SE edge of the craton of Man ([Abouchami et al., 1990], [Boher et al., 1992], [Kouamelan et al., 1997a] and [Kouamelan et al., 1997b]). The TTG and greenstone complexes would derive from the differentiation of "oceanic type" crustal units ([Abouchami et al., 1990], [Boher et al., 1992], [Pouclet et al., 1996] and [Dia et al., 1997]). The Eburnean orogeny is defined as the deformation and metamorphic events affecting the Paleoproterozoic continental crust during Birimian times, in western Africa. The present study focuses on the evolution of this orogenic event throughout the central and eastern part of the Paleoproterozoic domain of WAC, within Ivory Coast. 
At regional scale, the cartographic pattern of the studied domain is characterised by an alternation of narrow "bands" of TTG, greenstones, volcano-sedimentary series and leucogranites striking roughly N035 (Fig. 1 and Fig. 2a). Numerous strike-slip faults and ductile shear zones are recognised across the overall Paleoproterozoic province (Fig. 1), mostly striking NE to the northeast of the domain (cf. Ouagadougou area) and striking $\mathrm{N}$ in its central part.

In the following, a structural analysis is presented for three domains, the Nassian (NE), the Ferkessedougou (central West) and the South Comoé (SE) domains, and will focus on two pluton massifs considered as the references in the geological units' determinations in Ivory Coast ([Junner, 1940], [Bodin, 1951], [Arnould, 1961], [Tagini, 1971], [Casanova, 1973], [Bard, 1974] and [Yobou, 1993]). These plutons are: i) the Bondoukou massif (2.16 Ga; Touré et al., 1987), located within the Nassian domain, which is regarded as one of the first plutonic intrusions during the Eburnean crust formation event and ii) the Ferkessedougou massif (2.1 Ga; Yobou, 1993), within the central west part of the domain, considered as one of the late intrusions, synchronous with regional-scale shortening.

\section{Plutonic activity and metamorphic conditions during the Eburnean orogeny}

Many granitoid bodies are scattered across the West African Paleoproterozoic domain. A compilation of their radiometric ages has been done for the central-eastern part of the domain, in Ivory Coast (Fig. 2a) and it shows a very large span of ages, from about 2.2 to $2.0 \mathrm{Ga}$ (see references in the caption of Fig. 2). From a radiometric study made in the Kéniéba and Kayes areas (Senegal, Fig. 1), Hirdes and Davis (2002) divided the Paleoproterozoic domain of WAC in one older Eastern subprovince and a younger Western one. At the scale of the present work, no particular spatial trend or clustering of the ages can be shown across the domain (Fig. 2a). The Western subprovince of Hirdes and Davis (2002) may thus be limited to a zone lying further west of the studied area. Both time and spatial distribution of the radiometric ages highlight that the production of consequent volumes of magmas lasted during the overall Eburnean orogeny and that the magma production and intrusion rate was approximately the same across most of the domain during the continental growth. This suggests also that the geotherm remained rather high during the overall Eburnean orogeny.

A compilation of published metamorphic conditions estimations for different locations of the domain shows that, at regional scale, the entire Paleoproterozoic domain displays rather low maximum metamorphic conditions corresponding to greenschist facies to lower amphibolite metamorphic one (Fig. 2a; [Tagini, 1971], [Bard, 1974], [Guibert and Vidal, 1984], [Lemoine, 1988], [Delor et al., 1992a], [Delor et al., 1992b], [Siméon et al. 1995a], [Vidal et al., 1996], [Pouclet et al., 1996], [Doumbia et al., 1998], [Ouattara, 1998], [Gasquet et al., 2003] and [Pouclet et al., 2006]). To the east, the central part of the Comoé basin (cf. area 2 on Fig. 1) displays even lower anchizonal metamorphic conditions. Higher metamorphic conditions (HT / L to MP) have been reported in the Paleoproterozoic domain, along the edge of the Archean craton of Man: i) in its southwesternmost part, with a spatial progressive increase of metamorphic conditions, from NE to SW (Papon, 1973; Fig. 2a) or ii) at local scale, in association with granitic plutons (Caby et al., 2000). In other places of the Paleoproterozoic domain, some migmatites have also been notified but detailed petrographic analysis have shown that most of these units are, in fact, alternations of granitoids and orthogneisses which are not the result of a regional metamorphism (i.e. [Delor et al., 1992a] and [Delor et al., 1992b], 1994; [Vidal et al., 1996], [Castaing et al., 2004] and [Pouclet et al., 2006]). At local scale, a progressive increase of the metamorphic conditions, from greenschist to amphibolite 
facies, has been registered into the volcanic and sedimentary rock series as illustrated in the basin of the South Comoé domain (Fig. 2b). These metamorphic gradients are typically concentric around the granitoid massifs with a systematic increase of the metamorphic conditions, toward the plutons, on distances of a few to ten kilometres (cf. arrows on Fig. 2b). Detailed petrographic analyses have never been performed, throughout the Comoé domain, to quantify metamorphic conditions increase when approaching the plutons. However, works from Pons et al. (1995; NE WAC) and Debat et al. (2003; N WAC3) highlight a temperature, but also a pressure increase within the aureoles of syn-kinematic plutons. Outside of these peculiar pluton rim zones, HP/LT type metamorphic conditions have never been reported for any of the units of the Paleoproterozoic domain. Moreover, no sharp metamorphic jump has been described within the domain and changes of metamorphic conditions appear to be always continuous, either at regional or at local scale around the plutons (Fig. 2b). These two latter points suggest that no juxtaposition of contrasted metamorphic units along major thrusts or detachments occurred during the Eburnean orogeny.

\section{The Nassian domain: vertical movements without horizontal shortening}

\subsection{Geological setting}

The Nassian domain is located in the north-east part of Ivory Coast (zone 1, Fig. 1 and Fig. 2a). It makes part of a larger geological domain that extends to the north and east of the Paleoproterozoic domain (Fig. 1) and includes the Boutourou, Nassian, Kinnta and Bondoukou areas (Fig. 3a). To the south, the Nassian domain is limited by the northern edge of the Comoé sedimentary basin (Comoé domain, Fig. 2a). The contact of the Comoé series on top of the units of the Nassian domain has been rarely observed but clearly pointed out within the Upper Comoé area (Fig. 2a; Vidal et al., 1996). Its western boundary is defined by a late two-micas granite (Awahikro massif, Fig. 3a) similar to the Ferkessedougou granite described in the following part and lying along a sub-meridian regional-scale sinistral ductile shear zone. Field observations and cartographic relationships suggest that this ductile shear zone is a late structure relative to the deformation of the Nassian domain ([Vidal and Guibert, 1984] and [Vidal, 1987]). The Nassian domain is made of tonalite, trondjhemite and granodiorite (TTG) rocks suite emplaced into a series of dense volcanic and volcanosedimentary rocks (greenstones; Fig. 3a). Such volcano-sedimentary series comprise detrital formations - sandstones, quartzites, ampelites and pelites - interstratified with volcanic levels including rhyolites, andesites and basalts. At regional scale, the geological map shows that the volcano-sedimentary rocks are surrounding several granitoid plutons of one to several tens of kilometres width (Fig. 3a). The most studied of these plutons is the Bondoukou granodiorite, lying in the South-easternmost part of the Nassian domain (Fig. 3a). In map view, most of the plutons, such as the Bondoukou granodiorite, display a nearly circular shape (Fig. 3a). Such feature could be interpreted as resulting from intrusion of granitoids post-dating the deformation observed in the surrounding rocks. However, different studies documented a continuous chemical transition in-between granodioritic rocks and the tholeitic type volcanic series ([Tagini, 1971] and [Zéade et al., 1995]), suggesting a coeval origin for the TTG and the greenstones.

Radiochronological studies highlighted that these volcanic and plutonic units of the Nassian domain where synchronous and emplaced quite early during Birimian, from 2.2 to $2.15 \mathrm{Ga}$ ([Delor et al., 1995b] and [Siméon et al., 1994]; Zéadé et al., 1995). The age of $2195 \pm 10 \mathrm{Ma}$ calculated for a meta-rhyolite lying to the north of the domain ( $\mathrm{Pb} / \mathrm{Pb}-$ Zircon, Siméon et al., 
1995b; see Fig. 2a for location) is the oldest age known for the Paleoproterozoic units of the domain.

\subsection{Structural analysis of the TTG units (Nassian domain) with a particular focus on the Bondoukou granodiorite}

The Bondoukou granodiorite is considered as a typical example of a plutonic, nearly circular body, surrounded by deformed volcano-sedimentary rocks in the Nassian domain (Fig. 3a; [Delor et al., 1995b] and [Zéade et al., 1995]). The most common litho-facies of the Bondoukou pluton is a massive, hetero-granular with poor K-feldspar proportion granodiorite. In some places, a hypo-volcanic type facies can be observed, which displays amphibole and millimetre-scale rounded quartz minerals. It represents an intermediate composition suggesting geochemical filiations with the surrounding volcanic series (e.g. rhyolites and basalts). In the central part of the Bondoukou massif, the granodiorite is rather isotropic. The contact between the granodiorite and the volcano-sedimentary rocks has been studied along the northern edge of the pluton as its southern boundary is almost entirely covered by postBirimian deposits (Fig. 3a). From the core to the border of the Bondoukou massif, we observed a progressively increasing deformation. Within the rim of the pluton, the deformation is characterised by a penetrative foliation, clearly marked by biotite and hornblende minerals draping plagioclase phenocrysts. This foliation strikes parallel to the lithological contact and steeply dips outward from the pluton, draping the external envelope of the granodiorite. A mineral alignment to a stretching lineation has been observed as dip slip in those planes (Fig. 3b). Several kinematic criteria have been observed in the rim of the pluton: shear and foliation plane obliquity, asymmetrical rounded structures, which highlight a normal-type movement of the internal parts of the pluton relative to the surrounding rocks (Fig. 3b). In some places, the boundary between the granodiorite and the volcano-sedimentary units seems to be overturned; in that case the foliation is steeply dipping toward the pluton and kinematic criteria show inverse type movement coherent with the uprising of the central part of the granodiorite in regards to its surrounding rocks and its rim. From the edge toward the internal parts of the massif, the mineral stretching lineation tends to disappear, but some fine-grained dark inclusions display a sub-vertical alignment of Fe-Mg rich minerals, parallel to the measured orientation of the stretching lineations. Around these inclusions, the granodiorite display a rather isotropic texture which suggests that these alignments may correspond to magmatic lineations and that deformation was thus synchronous with the cooling and crystallisation of the pluton.

The structural and kinematic analysis presented for the Bondoukou granodiorite is a typical example that can be extrapolated to the other TTG massifs of the Nassian domain. The foliation trajectories have been extrapolated for the overall Nassian domain (Fig. 3a). Within the TTG units, foliation trajectories display as concentric ellipses, parallel to the lithological boundaries between the different plutonic massifs. If considering one isolated pluton, a preferential direction can be deduced for the long axis of the ellipse (for instance, $\mathrm{N}-\mathrm{S}$ for the Bondoukou granodiorite) and could be interpreted as perpendicular to a horizontal maximum shortening direction. However, the analysis of the trajectories' geometry, for the overall domain, show that these ellipses' long axes display scattered directions and that, in consequence, no preferential direction can be highlighted from those features. 


\subsection{Structural analysis of the greenstones (Nassian domain)}

Far from the plutons, the layering is well defined and preserved in the volcano-sedimentary series. The strike of the layering is almost parallel to the trace of the contact with the TTG units (Figs. 3a and c). Most of the time, it dips away from the plutons and more rarely toward them where the contact is overturned (Fig. 3a and c). At regional scale, the volcanosedimentary layers display upright narrow synclines squeezed between the different plutons (Fig. 3a and c). In map view, traces of these folds' axes turn around the TTG units without any clear preferred mean strike (Fig. 3a). At the vicinity of the plutons, the layering of the volcano-sedimentary series is progressively transposed by the development of a cleavage S1, parallel to the lithological contact between the two units (Fig. 3b). Mineral lineations L1 also developed within the greenstones, close to the contact with the plutons. The strike measured for these lineations show a radial dispersion around the plutons, from N300 to N020, with a rather steep plunge (50-70 .; Fig. 3a and b). Kinematic indicators (angle in-between cleavage and shear planes, asymmetrical micro-folds) show a normal-type movement, compatible with the one deduced from the structures observed within the external rim zones of the plutons (Fig. 3b).

Within the basic volcanic rocks, S1 is characterized by a dominant paragenesis consisting in "Chlorite + Epidote + Calcite + Quartz", defining greenschist metamorphic conditions. However, the amphibole blastesis (hornblende) underlying Ll near the plutons shows higher thermal conditions. In the rare pelitic facies mapped in contact with the Bondoukou granodiorite to the NW, this observation is confirmed by assemblages with syn- to postfoliation staurolite, implying minimum temperatures of about $550{ }^{\circ} \mathrm{C}$. The cartographic envelope of these maximum metamorphic conditions, as well as the foliation which is synchronous with them, drapes the contour of plutons.

The deformation field within the volcano-sedimentary units is strongly dependent on the geometry of the plutons. In cross section, the TTG plutons do not show strict intrusive relationships with the surrounding rocks because layers within the greenstone units drape the pluton domes and their layering is reoriented parallel to the contact envelope (Fig. 3c). As in the case of the TTG units, no preferential striking can be deduced from the analysis of the structures into the greenstone belts. Moreover, few triple-points have been recognized throughout the volcano-sedimentary units, as the one figured out along the Northern edge of the Bondoukou pluton (Fig. 3a). Cross sections of the Fig. 3b present very oblique directions (Fig. 3a). From one section to the other, the TTG plutons as well as the folds within the greenstones present respectively the same shape and roughly the same wavelength (Fig. 3c).

The structural analysis of the greenstones and the TTG units suggests that, at regional scale, there was no preferential horizontal shortening direction during the deformation of the Nassian domain. It suggests also that the structure of these units solely results from the vertical uprising of plutons relative to the surrounding rocks in absence of any tectonic boundary forces and implying only local-scale shortening, linked to internal body forces. 


\section{The Ferkessedougou domain: lateral flow during horizontal shortening}

\subsection{Geological setting of the Ferkessedougou domain}

The Ferkessedougou domain is located in the Ivory Coast, in the central part of the Paleoproterozoic domain (Fig. 1, area 2). This domain is made of i) a volcano-sedimentary series (sandstones, pelites and volcanics), considered as the lateral equivalent of the Comoé basin series and ii) the Ferkessedougou massif, a leucogranite "batholith" which extends on about $500 \mathrm{~km}$ long, from SW to NE, for a maximum of $50 \mathrm{~km}$ wide (Fig. 2a). Field observations and cartographic relationships show that the Ferkessedougou massif was a relatively late feature in this geological domain ([Milési et al., 1989] and [Doumbia et al., 1998]). This massif is regarded as one of the last magmatic intrusions during the Eburnean orogenic evolution (about $2.1 \mathrm{Ga}$ ) in the area ([Tagini, 1971], [Yobou, 1993] and [Doumbia et al., 1998]).

\subsection{Structural analysis of the Ferkessedougou domain}

The Ferkessedougou domain is characterized by the presence of several sub-meridian ductile shear zones, underlined by mylonites, which cut across the domain and draw sometimes anastomosed pattern, in map view (Fig. 1 and Fig. 4). Close to the shear zones, steep foliation planes and associated sub-horizontal mineral lineations developed into the surrounding rocks (Fig. 4). The obliquity between the strike of the foliation planes (and lineations) and the direction of the regional-scale shear zones suggests that these structures developed in a sinistral movement context (Fig. 4). Kinematics criteria observed on different outcrops (see location on Fig. 4) suggest also sinistral simple-shear movements (Fig. 5a).

Away from these regional-scale shear zones, layering of the volcano-sedimentary rocks is preserved and displays upright folds with axes striking N030 to N040, parallel to the direction of the Ferkessedougou granite. Sub-vertical cleavage developed parallel to their axial planes. Locally, stratification planes of the volcano-sedimentary series remain sub-horizontal and only gently folded (e.g. western Marahoué Basin, Fig. 4). In those places, a high density of quartz and/or pegmatitic dykes suggests the occurrence of a pluton, or of apophyses of a pluton at shallow depth, below the volcano-sedimentary series.

\subsection{Structural analysis of the Ferkessedougou leucogranite}

The Ferkessedougou massif is made quite exclusively by a biotite and muscovite rich granite facies which presents phase's equilibriums showing maximum metamorphic conditions in the greenschist facies (Doumbia et al., 1998). Biotite retromorphosis gives either secondary muscovite or chlorite with Fe oxides mineral assemblages. Away from the shear zones, the Ferkessedougou granite displays zones with contrasted deformation intensity marked by the development of rather strong fabrics (Fig. 5b) or cryptic structures (Fig. 5c). In the more intensely deformed zones, some stretching lineations developed without any evidence of associated cleavage or foliation planes. Such lineations are always sub-horizontal and strike N030-N035, parallel to the long "axis" of the elongated shape of the granite massif (Fig. 4). Within the low deformed zones, structures are poorly expressed and difficult to observe. Nevertheless, a detailed structural and remote sensing analysis, using SPOT-XS images, has been done in one of such poorly deformed zones within the Ferkessedougou granite massif, east of Zuénoula (see location on Fig. 4). The lineaments' interpretation made from remote sensing analysis shows that the Ferkessedougou "batholith" is constituted, in fact, by several 
different plutons or plutons' apexes (Fig. 6a). Fabric anisotropy is marked in the granite by biotite grains alignment and, sometimes, the stretching of schlieren structures. Two families of plane anisotropies are identified (Fig. 6a): i) sub-horizontal ones, marked by sub-horizontal jointing at outcrop-scale (Fig. 5d), and ii) steep ones, striking parallel to the stretching lineations which have been measured in the more intensely deformed zones (Fig. 6a). The linear anisotropies are always sub-horizontal and show two different direction families (Fig. 6a): one striking SW, also parallel to the measured stretching lineations, and one striking perpendicularly, oblique to the cartographic "elongation" of the Ferkessedougou granite (Fig. 6a). Orientations of the planar and linear anisotropies measured on the field are in good accordance with the ones obtained by Ouattara (1998) from a magnetic susceptibility analysis study held in the same area (compare Fig. 6a and b).

The Ferkessedougou leucogranite presents a constrictive deformation with a N030-N035 oriented horizontal maximum stretching direction. This deformation pattern is compatible with the one observed within the surrounding volcanic and sedimentary series which shows N030-N035 oriented upright folds suggesting a N120-N125 oriented horizontal maximum shortening direction. In that frame, the cryptic deformation pattern measured into the low intensity deformation zones of the pluton can be interpreted as the combination of regionalscale deformation (cf. sub-vertical planes and NNE-SSE striking lineations) and of local ballooning of the plutons during their intrusion (cf. sub-horizontal planes combined with oblique lineations). These features suggest that, during its emplacement, the Ferkessedougou granite was flowing in a horizontal direction, at a high angle with the regional-scale maximum horizontal shortening.

\section{The South Comoé domain: combined horizontal shortening and vertical movements}

\subsection{Geological setting of the South Comoé domain}

The study of this domain allows linking the structures observed within the Nassian and the Ferkessedougou domains. The South Comoé domain is located to the S-SE of the Paleoproterozoic domain, north of Abidjan (area 3, Fig. 1). This domain is mainly constituted by a terrigeneous sedimentary series comprising sandstones with a phyllitic matrix, arkoses and pelitic layers (Fig. 7a; [Alric et al., 1987], [Vidal, 1987], [Delor et al., 1992a] and [Delor et al., 1992b]). Into the series, sedimentological studies highlight a bad size sorting and angular shapes of the grains. In most places, far from the granite plutons, syn-sedimentary structures have nicely been preserved: e.g. soft pebbles, load casts, slumps. The Comoé series corresponds to rather low energy conditions during the transport and deposit of the sediments; the basin was thus close to the erosion source that presented a moderate relief ([Alric et al., 1987] and [Vidal et al., 1996]). Several granitoid plutons outcrop throughout the South Comoé domain (Fig. 7a). Leucogranites are clearly emplaced within the Comoé sedimentary series and do correspond to late leucogranites similar to the Ferkessedougou massif, lying further west. However, some other granitoids comprising deformed granodiorites and tonalites appear to pre-date sedimentary deposits. Indeed, even if the contact surface between the sediments and these latter granitoid massifs has never been directly observed on the field, the absence of contact metamorphism around indicates that the sedimentary series must have deposited on top of those granites. These massifs may correspond to the TTG complex units of the Nassian domain which emplaced very early during the Eburnean history. 
At first order, the metamorphic conditions recorded in the South Comoé sedimentary series correspond to the greenschist metamorphic facies (Fig. 2). In more details, maximum metamorphic conditions progressively increase locally when approaching some of the pluton massifs and can reach amphibolite facies conditions at the contact with the granite bodies (Fig. 2b; [Tagini, 1971], [Bard, 1974], [Bard and Lemoine, 1976], [Vidal and Guibert, 1984], [Delor et al., 1992a] and [Delor et al., 1992b]). This metamorphic gradient is characterised by temperature but also pressure increase. Even if localised around the leucogranites, this cannot be simply interpreted as a contact metamorphism due to their intrusion within the sedimentary basin. Deeper structural levels of the surrounding rocks look to have been turned up around the leucogranite plutons during their emplacement.

\subsection{Structural analysis of the leucogranites}

In map view, envelopes of the late leucogranite display as elongated bodies oriented in the same NE to NNE direction (Fig. 7a). In some places, these plutons are located along localscale strike-slip shear zones (Fig. 7a and b). In the core of the massifs, a clear NE striking sub-horizontal mineral lineation developed, parallel to the long direction of the plutons (Fig. 8a). In the rim zones of the granites, two different kinds of structures have been observed. First, foliation planes developed roughly parallel to the contact surface between the granite and the surrounding sedimentary series, i.e. dipping away from the centre parts of the granites. Dip-slip lineations are associated with the development of such foliations and some kinematic criteria indicate normal-type movements along those planes (Fig. 8b and c). In other places, where plutons are located along ductile shear zones, simple-shear type structures developed within the leucogranites with a steep foliation, horizontal stretching lineations and kinematic criteria (foliation/shear planes obliquity) showing systematic sinistral movements along the shear zones.

\subsection{Structural analysis of the volcano-sedimentary series}

The deformation pattern of the volcano-sedimentary series is marked by upright folds presenting contrasted wavelength from one place to another (Fig. 7 and Fig. 9). Sub-vertical cleavage sometimes developed, parallel to mean axial planes of the folds (Fig. 9b). Cleavage and fold axes strike NNE to NE, parallel to the mean orientation of the elongated shape of the leucogranite plutons (Fig. 7 and Fig. 8). These structures are compatible with the N120 to N130 striking maximum horizontal shortening direction deduced from the structural analysis of the Ferkessedougou domain. In addition, the envelope of the folds is sub-horizontal across the overall domain (Fig. 7 and Fig. 8) which indicates a homogeneous deformation at regional scale. Locally, the bedding can present rather gentle folding where the volcano-sedimentary series is observed directly on top of a leucogranite pluton (Fig. 8 and Fig. 9). These observations suggest that, at least some, leucogranites emplaced before the end of the WNW directed shortening and thus partly controlled the net shortening within the overlying sedimentary cover. At the vicinity of the leucogranites, the cleavage in the volcanosedimentary rocks becomes roughly parallel to the lithological contact (Fig. 8 and Fig. 9) with a dip-slip mineral lineation. Shear criteria often display down-dip movements (Fig. 8b and c).

The structural analysis of the Comoé domain highlights that the deformation pattern is rather homogeneous across the entire basin, and that leucogranites emplacement was coeval with N120 to N130 oriented regional-scale horizontal shortening. In addition, it shows that the emplacement of the leucogranites was mainly associated with i) normal-type, down-dip movements, along their boundaries, within the leucogranite and surrounding rocks and ii) a 
turn up of the deeper levels of the basin, resulting in a pressure and temperature increase of the metamorphic estimations, around the plutons. These features suggest that the leucogranites emplaced by diapiric ascent into the upper crust during the horizontal shortening event that affected the Paleoproterozoic domain during the Eburnean evolution.

\section{Discussion and synthesis}

Results of the analysis of the Nassian domain shows that structures' orientations are similar within the TTG and the greenstones; cleavage trajectories are always concentric around the pluton domes and, at regional scale, the strain field does not present any preferential horizontal shortening direction (cf. sketch diagram I, Fig. 10). The analysis of the kinematic criteria also shows similar movements into the different lithologies, with ductile pervasive normal movements of the cores of the plutons relative to their rims and surrounding rocks. Such a deformation pattern well corresponds to "archaic-type" mechanisms of diapiric ascent of the TTG units and relative sagduction of the greenstones, which present a highest mean density, during a period when no tectonic forces applied at the boundaries of the domain. Such deformation pattern is rather similar to "domes and basins" geometries, commonly observed within Archean orogens ([Bouhallier et al., 1995], [Choukroune et al., 1995], [Chardon et al., 1998] and [Chardon et al., 2002]). Previous studies have underlined i) geochemical affinities of rock compositions ([Tagini, 1971] and [Zéade et al., 1995]), and ii) similar radiometric ages ([Siméon et al., 1994], [Delor et al., 1995b] and [Zéade et al., 1995]) in-between the TTG and greenstone units. The plutonic and volcanic rocks have emplaced during a continuous magmatic event, between 2200 and $~ 2150 \mathrm{Ma}$; indeed, the oldest radiometric age interpreted as the emplacement of Paleoproterozoic units, in Ivory Coast, has been obtained from rocks from the Nassian domain (2195 $\pm 10 \mathrm{Ma} \mathrm{Pb} / \mathrm{Pb}-\mathrm{Zr}$; Siméon et al., 1995b). In addition, the intrusion of the TTG plutons, coeval with their deformation, has been dated at about $\sim 2170-2150$ Ma (cf. compilation on Fig. 2a). From all these features, the structure of the Nassian domain must be regarded as a witness of the earliest stage during the Eburnean-Paleoproterozoic-orogeny evolution, with deformations that may be solely driven by body forces (cf. I, Fig. 10).

After $2150 \mathrm{Ma}$, fine-grained clastic sediments began to deposit on large areas, on top of the TTG-greenstone complexes; the Nassian domain then formed a limited relief, uplifted along the N130-N150 oriented faults that mark out the northernmost extension of the Comoé sedimentary basin ([Vidal, 1987] and [Vidal et al., 1994]).

The second stage of the Eburnean orogeny - around $2100 \mathrm{Ma}$ - is marked by the emplacement of leucogranite bodies into the upper crust, coeval with a WNW oriented regional-scale shortening (Fig. 10). This magma production could result from the partial melting of older TTG and greenstone complexes ([Doumbia, 1997] and [Pouclet et al., 2006]) corresponding to the onset of a geochemical recycling of continental crust material.

Results of early studies within the Upper Comoé domain suggest that the Comoé sedimentary basin could correspond to a transtensional basin developed in a back-arc context (Vidal and Alric, 1994). However, as described before, the Comoé sedimentary series correspond to a basin much larger than the surface outcropping throughout the studied area and was certainly located close to the erosion source (Vidal et al., 1996). In addition, the lack of deposit of coarse-grained clastic sediments in the Ivory Coast, during Birimian, indicates that the relief remained moderate during the whole of the Eburnean orogeny. In contrast with previous interpretations, this work highlights that the Comoé sedimentary series may have deposited on 
large areas, in a context of shallow continental basin. From a structural point of view, the analysis of the South Comoé domain highlights a rather simple deformation pattern. The volcanic and sedimentary rocks display upright folds with the development of a mean vertical cleavage, parallel to the axial plane, and striking N030 to N035. The folds display a subhorizontal envelope across the overall domain. In addition, the compilation of the metamorphic estimations underlines that the volcano-sedimentary series displays constant maximum PT conditions across the Comoé basin (Fig. 2); the same structural level does outcrop overall South Comoé domain and remained sub-horizontal when it deformed. All these features are compatible with a homogeneous and pervasive deformation regime of the crust, during the whole of the Eburnean history, and do not fit with classical "modern-type" orogenic models where main crustal thrust develop and allow the juxtaposition of contrasted metamorphic units as already proposed ([Milési et al., 1989], [Ledru et al., 1990] and [Feybesse and Milési, 1994]). The structural relationships between the leucogranites and the volcano-sedimentary series of the South Comoé domain also points out that the plutons did not cut across the bedding and structure of the sedimentary basin; their emplacement much better correspond to diapiric uprising of the leucogranites and a relative downward movement of the surrounding rocks during regional-scale horizontal shortening. The Ferkessedougou massif is a typical example of the late leucogranites that can be found within the overall Paleoproterozoic domain in Ivory Coast. The Ferkessedougou domain displays a rather deeper erosion level within the crust and its deformation pattern and structure may correspond to the one that could be observed within the relative basement of the Comoé basin, just below the volcano-sedimentary cover. Our structural analysis of the Ferkessedougou "batholith" shows that its constrictive deformation pattern may result from the competition in-between the ballooning of the plutons that constitute the massif and a regional-scale N120-N130 oriented maximum shortening. It highlights the coeval tectonic and plutonic activities during the second stage of the Eburnean orogeny. Throughout Ivory Coast, most of the granites of that type - and age - present an elongated cartographic shape. In the case of the Ferkessedougou massif, its longest direction is almost parallel to the strike of its stretching lineation. In addition, some ductile shear zones often developed along the edges of the granites. These features may be interpreted as the result of a horizontal flowing of the leucogranite bodies, at high angle to the regional-scale horizontal shortening, during their emplacement, with the shear zones acting as transfer zones of the differential movement with surrounding rocks. The sinistral movements often deduced from the kinematics analysis of these sub-meridian shear zones would highlight for a systematic obliquity with the maximum shortening direction in a transpressive tectonic regime ( $c f$. Vidal and Alric, 1994). From previous works, numerical experiments on soft and buoyant type lithospheres have shown that a phase of orogen-parallel constriction flow takes place as tectonic forces decrease, during a late stage of a weak-type orogeny evolution (Duclaux et al., 2007). The structure of the Ferkessedougou massif and the ductile shear zones associated with may thus mark out the late stage of development of the weak-type orogeny within the Birimian juvenile crust of western Africa. 


\section{Conclusions}

Different concluding points can be drawn from this work:

1- The Paleoproterozoic domain of Ivory Coast displays a homogeneous and pervasive ductile deformation with no metamorphic contrast at regional scale,

2- The granitoids emplaced by diapiric uprising within the crust, and relative burial of the upper-crust units, during the whole of the Eburnean history. This long-lived character is in accordance with "archaic" type models of evolution where important vertical motions are documented,

3- The Eburnean history presents a continuous evolution from i) uprise of the TTG and sagduction of greenstones solely driven by body forces in absence of any horizontal shortening, to ii) coeval vertical movements and regional-scale horizontal shortening,

4- The Nassian domain, located NE of the Ivory Coast, can be considered as a witness of the early developed structures which have been preserved, as a rigid block, from subsequent deformation during the Eburnean orogeny,

5- During the first stage of evolution, vertical movements of the crustal units can easily be attributed to inverse density gradients of the dense greenstones lying on top of the TTG units. In contrast, during the second stage, vertical-type diapiric movements persist within a lithological "pile" of clastic sediments lying above granitoids, which do not show any inverse density gradient,

6- During a second phase of evolution, coeval uprising of granite diapirs and regional-scale shortening brings to a horizontal flow of the plutons at high angle with the maximum shortening direction. It results in a horizontal stretching of the granite,

7- Horizontal stretching of the leucogranites is associated with the development of ductile shear zones that act as transfer zones along the pluton boundaries.

\section{Acknowledgements}

We are first grateful for helpful reviews by G. Duclaux and the anonymous referees. Field works in the Bondoukou area have been performed in the frame of a project directed by the Direction de la Géologie of the Côte d'Ivoire government and with technical help from the $B R G M$, France. Special thanks for the French project leader, Mr Delor C. (BRGM) for his scientific collaboration on the field and very useful help for the part treating of the Bondoukou graniodorite. This project has been funded by the French Cooperation and Help program. Field works in the Ferkessedougou area have been done with the technical help of the SODEMI, Côte d'Ivoire. Particular thanks go to Mrs N'Zi, Diaby and Yao, former and present directors of the SODEMI and the Direction de la Géologie of the Côte d'Ivoire government. 


\section{References}

Abouchami et al., 1990 W. Abouchami, M. Boher, A. Michard and F. Albarède, A major $2.1 \mathrm{Ga}$ event of mafic magmatism in West Africa: an early stage of crustal accretion, $J$. Geophys. Res. 95 (11) (1990), pp. 17605-17629.

Adou et al., 1995 M. Adou, C. Delor, Y. Siméon, Z. Zamblé, G. Konan, B.D. Yao, M. Vidal, I. Diaby, J.P. Cautru, J.C. Chiron, A. Dommanget and A. Cocherie, Carte géologique de la Côte-d'Ivoire 1/200000, feuille Abengourou, Direction des mines et de la géologie, Abidjan, Côte-d'Ivoire (1995).

Alric et al., 1987 G. Alric, P. Guibert and M. Vidal, Le problème des grauwackes birrimiennes de Côte d'Ivoire: une revue et des données nouvelles, C.R. Acad. Sci. Paris 304 (II) (1987), pp. 289-294.

Arnould, 1961 M. Arnould, Etude géologique des migmatites et granites précambriens du Nord de la Côte-d'Ivoire et de la Haute-Volta méridionale. Mém. BRGM, Fr (1961) 174 p.

Bard, 1974 J.P. Bard, Remarques à propos de l'évolution géotectonique du craton OuestAfricain en Côte-d'Ivoire, C.R. Acad. Sci. Paris 278 (D) (1974), pp. 2405-2408.

Bard and Lemoine, 1976 J.P. Bard and S. Lemoine, Phases tectoniques superposées dans les métasédiments précambriens du domaine côtier occidental de la Côte d'Ivoire, Precambrian Res. 3 (1976), pp. 209-229.

Billa et al., 1999 M. Billa, J.L. Feybesse, G. Bronnet, C. Lerouge, J.P. Milési, S. Traoré and S. Diaby, Les formations à quartzite rubanés ferrugineux des Monts Nimba et du Simandou: des unités empilées tectoniquement, sur un « soubassement » plutonique Archéen (craton de Kénéma-Man), lors de l'orogène Eburnéen, Earth Planet. Sci. Lett. 329 (1999), pp. 287-294.

Bodin, 1951 L. Bodin, Contribution à l'étude des granites birrimiens dans le Précambrien de l'Afrique occidentale, Bull. Dir. Mines A.O.F., Dakar vol. 12 (1951) 113 pp.

Boher et al., 1992 M. Boher, W. Abouchami, A. Michard, F. Albarède and N. Arndt, Crustal growth in West-Africa at 2.1 Ga, J. Geophys. Res. 97 (1992), pp. 345-369.

Bouhallier et al., 1995 H. Bouhallier, D. Chardon and P. Choukroune, Strain patterns in Archaean dome and basin structures: the Darwar craton (Karnakata, South India), Earth Planet. Sci. Lett. 135 (1995), pp. 57-75.

Caby et al., 2000 R. Caby, C. Delor and O. Agoh, Lithologie, structure et métamorphisme des formations Birimiennes dans la région d'Odienné (Côte d'Ivoire): rôle majeur du diapirisme des plutons et des décrochements en bordure du craton de Man, J. Afr. Earth Sci. 30 (2) (2000), pp. 351-374

Caen-Vachette, 1986 M. Caen-Vachette, Apport de la géochronologie isotopique à la connaissance du Protérozoïque Inférieur de l'Afrique de l'Ouest, Publication CIFEG, 1986/10. Les formations birimiennes en Afrique de l'Ouest (1986), pp. 17-23. 
Cagnard et al., 2006a F. Cagnard, J.P. Brun and D. Gapais, Modes of thickening of analogue weak lithospheres, Tectonophysics 421 (2006), pp. 145-160.

Cagnard et al., 2006b F. Cagnard, N. Durrieu, D. Gapais, J.P. Brun and C. Ehlers, Crustal thickening and lateral flow during compression of hot lithospheres, with particular reference to Precambrian times, TerraNova 18 (2006), pp. 72-78.

Cagnard et al., 2007 F. Cagnard, D. Gapais and P. Barbey, Collision tectonics involving juvenile crust: the example of the southern Finnish Svecofennides, Precambrian Res. 154 (12) (2007), pp. 125-141.

Casanova, 1973 Casanova, R., 1973. Géochimie et minéralogie des granitoïdes éburnéens de Côte-d'Ivoire. Thèse Doct. és Sciences, Univ. Nice -Univ. Abidjan, 327 p.

Castaing et al., 2003 C. Castaing, J. Le Métour, M. Billa, M. Donzeau, P. Chèvremont, E. Egal, B. Zida, I. Ouedraogo, S. Koté, E. Kaboré, C. Ouédraogo, D. Thiéblemont, C. Guerrot, A. Cocherie, M. Tegyey, J.P. Milési and Y. Itard, Carte géologique et minière du BurkinaFaso à 1/1000000, Orléans: Ed. BRGM (2003).

Castaing et al., 2004 C. Castaing, D. Thiéblemont, P. Chèvremont, M. Donzeau, E. Egal, C. Guerrot, S. Koté, I. Ouédraogo, A. Cocherie and J. Le Métour, Paleoproterozoic crustal evolution in Burkina Faso (West African craton), IGC 32nd. International Geological Congress, Florence, Italie (2004) 20-28/08/2004.

Chardon et al., 1996 D. Chardon, P. Choukroune and M. Jayananda, Strain patterns, décollement and incipient sagducted greenstone terrains in South India, J. Struct. Geol. 18 (1996), pp. 991-1004.

Chardon et al., 1998 D. Chardon, P. Choukroune and M. Jayananda, Sinking of the Dharwar Basin (South India); implications for Archaean tectonics, Precambrian Res. 91 (1-2) (1998), pp. 15-39.

Chardon et al., 2002 D. Chardon, J.J. Peucat, M. Jayananda, P. Choukroune and C.M. Fanning, Archean granite-greenstone tectonic at Kolar (South India): interplay of diapirism and bulk inhomogeneous contraction during magmatic juvenile accretion, Tectonics 21 (2002) 10.1029/2001TC901032.

Choukroune et al., 1995 P. Choukroune, H. Bouhallier and N.T. Arndt, Soft lithosphere during periods of Archaean crustal growth or crustal reworking. In: M.P. Coward and A. Ries, Editors, Early Precambrian Processes, Geol. Soc. London Spec. Publ. vol. 95 (1995), pp. 6786.

Debat et al., 2003 P. Debat, S. Nikiéma, A. Mercier, M. Lompo, D. Béziat, F. Bourges, M. Roddaz, S. Salvu, F. Tollon and U. Wenmenga, A new metamorphic constraint for the Eburnean orogeny from Paleoproterozoic formations of the Man shield (Aribinda and Tampelga countries, Burkina Faso), Precambrian Res. 123 (2003), pp. 47-65.

Delor et al., 1991 C. Delor, J.P. Burg and G. Clarke, Relations diapirisme-métamorphisme dans la province du Pilbara (Australie Occidentale): implications pour les régimes thermiques et tectoniques à l'Archéen, C.R. Acad. Sci. Paris 312 (1991), pp. 257-263. 
Delor et al., 1992a C. Delor, I. Diaby, J.P. Tastet, B. Yao, Y. Siméon, M. Vidal and A. Dommanget, Notice explicative de la carte géologique de la Côte-d'Ivoire $\wedge 1 / 200000$, feuille d'Abidjan. Ministère des Mines et de l'Energie, DMG, Abidjan, Côte-d'Ivoire (1992).

Delor et al., 1992b C. Delor, I. Diaby and B.D. Yao, Notice explicative de la carte géologique de la Côte-d'Ivoire 1/200 000, feuille de Grand-Bassam. Ministère des Mines et de l'Energie, DMG, Abidjan, Côte-d'Ivoire (1992).

Delor et al., 1992c C. Delor, I. Diaby, Y. Siméon, M. Adou, Z. Zamblé, J.P. Tastet, B.D. Yao, G. Konan, J.C. Chiron and A. Dommanget, Carte géologique de la Côte-d'Ivoire 1/200000, feuille Grand-Bassam, Direction des mines et de la géologie, Abidjan, Côte-d'Ivoire (1992).

Delor et al., 1995a C. Delor, Y. Siméon and M. Vidal, Peri-plutonic gravity driven deformations and transcurrent tectonics between 2.2 and 2.1 By: a case study from the Birimian Cycle in Ivory Coast (1995) EUG 8, Strasbourg, 9-13 april 1995, abstract, 102.

Delor et al., 1995b C. Delor, Y. Siméon, M. Vidal, Z. Zéadé, Y. Koné, M. Adou, J. Dibouahi, D. Bi-Irié, B.D. Yao, D. N'Da, A. Pouclet, G. Konan, I. Diaby, J.C. Chiron, A. Dommanget, A. Kouamelan, J.J. Peucat, A. Cocherie and J.P. Cautru, Carte géologique de la Côte-d'Ivoire 1/200000, feuille de Nassian. Ministère des Mines et de l'Energie. DMG, Abidjan, Côted'Ivoire (1995).

Dia et al., 1997 A. Dia, W.R. van Schmus and A. Kröner, Isotopic constraints on the age and formation of a Palaeoproterozoic volcanic arc complex in the Kedougou Inlier, eastern Senegal, West Africa, J. Afr. Earth Sci. 24 (3) (1997), pp. 197-213.

Doumbia, 1997 Doumbia, S., 1997. Géochimie, géochronologie et géologie structurale des formations birimiennes de la région de Katiola-Marabadiassa (centre-nord de la Côted'Ivoire). Thèse, Université d'Orléans, 214 p.

Doumbia et al., 1998 S. Doumbia, A. Pouclet, A. Kouamelan, J.P. Peucat, M. Vidal and C. Delor, Petrogenesis of juvenile-type Birimian (Palaeoproterozoic) granitoids in Central Côted'Ivoire, West-Africa: geochemistry and geochronology, Precambrian Res. 87 (1998), pp. 3363.

Duclaux et al., 2007 G. Duclaux, P. Rey, S. Guillot and R.P. Ménot, Orogen-parallel flow during continental convergence: numerical experiments and Archean field examples, Geology 35 (8) (2007), pp. 715-718.

Feybesse and Milési, 1994 J.L. Feybesse and J.P. Milési, The Archaean/Proterozoic contact zone in West Africa: a mountain belt of décollement thrusting and folding on a continental margin related to 2.1 Ga convergence of Archaean cratons?, Precambrian Res. 69 (1994), pp. 199-227.

Gapais et al., 2008 D. Gapais, A. Pelletier, R.-P. Ménot and J.-J. Peucat, Paleoproterozoic tectonics in the Terre Adélie Craton (East Antarctica), Precambrian Res. 162 (3-4) (2008), pp. 531-539. 
Gasquet et al., 2003 D. Gasquet, P. Barbey, M. Adou and J.L. Paquette, Structure, Sr-Nd isotope geochemistry and zircon $\mathrm{U}-\mathrm{Pb}$ geochronology of the granitoïds of Dabakala area (Côte d'Ivoire): evidence for a 2.3 Ga crustal growth event in the Palaeoproterozoic of West Africa?, Precambrian Res. 127 (2003), pp. 329-354.

Gorman et al., 1978 B.E. Gorman, T.H. Pearce and T.C. Birkette, On the structure of the Archaean greestone belts, Precambrian Res. 6 (1978), pp. 23-41.

Guibert and Vidal, 1984 P. Guibert and M. Vidal, Un modèle d'évolution structurale du Birrimien du Sud-Est de la Côte d'Ivoire, Ann. Univ. Abidjan C (1984), pp. 277-293 (XX).

Hirdes and Davis, 2002 W. Hirdes and D.W. Davis, U_/Pb Geochronology of Paleoproterozoic rocks in the Southern part of the Kedougou-Kéniéba Inlier, Senegal, West Africa: evidence for diachronous accretionary development of the eburnean province, Precambrian Res. 118 (2002), pp. 83-99.

Hirdes et al., 1992 W. Hirdes, D.W. Davis and B.N. Eisenlohr, Reassessment of Proterozoic granitoid ages in Ghana on the basis of U/Pb zircon and monazite dating, Precambrian Res. 56 (1992), pp. 89-96.

Hirdes et al., 1996 W. Hirdes, D.W. Davis, G. Lüdtke and K.G. Konan, Two generations of Birimian (Paleoproterozoic) volcanics belts in northeastern Côte d'Ivoire (West Africa): consequences for the "Bririmian controversy”, Precambrian Res. 80 (1996), pp. 173-191.

Junner, 1940 N.J. Junner, Geology of the Gold Coast and Western Togoland, Bull. Gold Coast Geol. Surv. 11 (1940).

Koné et al., 1995 Y. Koné, D.B. Irié, D. N'Da, Z. Zéadé, M. Adou, J. Dibouahi, C. Delor, Y. Siméon, M. Vidal, I. Diaby, B.D. Yao and A. Pouclet, Carte géologique de la Côte d'Ivoire à 1/200000, feuille de Nassian, mémoire n 9, Ministère des Mines et de l'Energie, Direction de la Géologie, Abidjan, Côte d'Ivoire (1995).

Kouamelan, 1996 Kouamelan, A.N., 1996. Géochronologie et géochimie des formations Archéennes et Protérozoïques de la dorsale de Man en Côte d'Ivoire. Mém. 73, Géosciences Univ. Rennes, France, 289 p.

Kouamelan et al., 1997a A.N. Kouamelan, J.J. Peucat and C. Delor, Reliques archéennes (3.15 Ga) au sein du magmatisme Birimien (2.1 Ga) de Côte d'Ivoire, craton Ouest-Africain, C.R. Acad. Sci. Paris 324 (1997), pp. 719-727.

Kouamelan et al., 1997b A.N. Kouamelan, C. Delor and J.J. Peucat, Geochronological evidence for reworking of Archean terrains during the Early Proterozoic (2.1 Ga) in the western Côte d'Ivoire (Man Rise - West African Craton), Precambrian Res.86 (1997), pp. 177-199.

Leake, 1992 Leake, M.H., 1992. The petrogenesis and structural evolution of the early Proterozoic Fettekro greenstone belt, Dabakala region, NE Côte d'Ivoire. Unpub. Thesis, Portsmouth, U.K., 315 p. 
Ledru et al., 1990 P. Ledru, M and J.P. ilési, Le Protérozoïque inférieur (Birrimien) du centre de la Côte d'Ivoire: évolution tectonique et corrélations, C.R. Acad. Sci. Paris 311 (1990), pp. 971-976.

Lemoine, 1988 Lemoine, S., 1988. Evolution géologique de la région de Dabakala (NE de la Côte-d'Ivoire) au Protérozoïque. Possibilités d'extension au reste de la Côte-d'Ivoire et au Burkina Faso: similitudes et différences; les linéaments de Greenville-Ferkéssédougou et Grand-Cess-Niakaramandougou. Thèse ès Sciences, Univ. Cl.-Ferrand, 388 p.

Lüdtke et al., 1992 Lüdtke, G., Hirdes, W., Konan, K.G., Koné, Y., N'Da, D., Traoré, Y., Zamblé, Z.B., 1992. Geology of the Haute Comoé south area, geological map 1: 100000, sheets Dabakala 2b, d and 4b, d, 1st ed. Ivorian-German Geological Cooperation Project (1995-1996).

Lüdtke et al., 1998 G. Lüdtke, W. Hirdes, G. Konan, Y. Koné, C. Yao and Z. Zamblé, Géologie de la région Haute Comoé Nord, Ministère des ressources minières et pétrolières de Côte d'Ivoire, Direction de la Géologie, Bull. vol. 1 (1998) 178 pp.

Milési et al., 1989 J.P. Milési, J.L. Feybesse, P. Ledru, A. Dommanget, M.F. Ouédraogo, E. Marcoux, A.E. Prost, C. Vinchon, J.P. Sylvain, V. Johan, M. Teguey, J.Y. Calvez and P. Lagny, Les minéralisations aurifères d'Afrique de l'Ouest. Leurs relations avec l'évolution lithostructurale au Protérozoïque inférieur, Chroniques Recherche Minière France, BRGM vol. 497 (1989), pp. 3-98.

Nikiéma et al., 1993 S. Nikiéma, J. Benkhelil, M. Corsini, F. Bourges, A. Dia and J.C. Marin, Tectonique transcurrente éburnéenne au sein du craton ouest-africain, C.R. Acad. Sci. Paris II 316 (1993), pp. 661-668.

Oberthür et al., 1998 T. Oberthür, U. Vetter, D.W. Davis and J.A. Amanor, Age constraints on gold mineralization and Paleoproterozoic crustal evolution in the Ashanti belt of southern Ghana, Precambrian Res. 89 (1998), pp. 129-143.

Ouattara, 1998 Ouattara, G., 1998. Structure du batholite de Ferkéssédougou (secteur de Zuénoula, Côte d'Ivoire). Thèse doctorat, Université d'Orléans, ISTO, Orléans, 291 pp.

Papon, 1973 A. Papon, Géologie et minéralisations du Sud-Ouest de la Côte d'Ivoire (opération SASCA), Mém. BRGM vol. 80 (1973) Orléans, 286 pp.

Pons et al., 1992 J. Pons, C. Oudin and J. Valéro, Kinematics of large syn-orogenic intrusions: example of the Lower Proterozoic Saraya batholith (Eastern Sénégal), Geol. Rundsch. 82 (2) (1992), pp. 473-486.

Pons et al., 1995 J. Pons, P. Barbey, D. Dupuis and J.M. Léger, Mechanisms of pluton emplacement and structural evolution of a $2.1 \mathrm{Ga}$ juvenile continental crust: the Birimian of southwestern Niger, Precambrian Res. 70 (1995), pp. 281-301.

Pouclet et al., 1996 A. Pouclet, M. Vidal, C. Delor, Y. Siméon and G. Alric, Le volcanisme birimien du nord-est de la Côte-d'Ivoire, mise en évidence de deux phases volcanotectoniques distinctes dans l'évolution géodynamique du Paléoprotérozoïque, Bull. Soc. Géol. Fr. 167 (4) (1996), pp. 529-541. 
Pouclet et al., 2006 A. Pouclet, S. Doumbia and M. Vidal, Geodynamic setting of the Birimian volcanism in Central Ivory Coast (Western Africa) and its place in the evolution of the Palaeoproterozoic of the Man Shield, Bull. Soc. Géol. Fr. 177 (2) (2006), p. 195-121.

Siméon et al., 1992 Y. Siméon, C. Delor, I. Diaby, G. Gadou, P. Kohou, J.P. Tastet, B.D. Yao, G. Conan and A. Dommanget, Carte géologique de la Côte-d'Ivoire 1/200000, feuille Abidjan, Direction des mines et de la géologie, Abidjan, Côte-d'Ivoire (1992).

Siméon et al., 1994 Y. Siméon, C. Delor, M. Vidal, A. M'Bé and A. Cocherie, Contraintes régionales sur le régime thermo-tectonique au cycle birimien (Nord de la Côte d'Ivoire), Comptes Rendus de la 15 ${ }^{\text {ème }}$ R.S.T., Nancy, 26-28 avril 1994 (1994).

Siméon et al. 1995a Y. Siméon, C. Delor, Z. Zéade, Y. Kone, B.D. Yao, M. Vidal, I. Diaby, G. Konan, D. Bi Irié, N'Da, A. Dommanget, J.P. Cautru, C. Guerrot and J.C. Chiron, Notice explicative de la carte géologique de la Côte d'Ivoire à 1/200000, feuille de AgnibilékrouKouamé-Dari, mémoire $n^{\circ}$ 8, Ministère des Mines et de l'Energie, Direction de la Géologie, Abidjan, Côte d'Ivoire (1995).

Siméon et al., 1995b Y. Siméon, C. Delor, M. Vidal and A. Cocherie, The "Birimian” Cycle of West Africa: new structural and isotopic constraints from Eastern Ivory Coast terrains, EUG 8, Strasbourg, 9-13 april 1995 (1995), p. 102 abstract.

Siméon et al., 1995c Y. Siméon, C. Delor, Z. Zéadé, Y. Koné, B.D. Yao, M. Vidal, I. Diaby, G. Konan, B. Djé, D. N'da, A. Dommanget, J.P. Cautru, C. Guérrot and J.C. Chiron, Carte géologique de la Côte-d'Ivoire 1/200000, feuille Agnibilékrou, Direction des mines et de la géologie, Abidjan, Côte-d'Ivoire (1995).

Tagini, 1971 B. Tagini, Esquisse structurale de la Côte d'Ivoire. Essai de géotectonque régionale. Thèse, Univ. Lausanne. Bull vol. 5, SODEMI, Abidjan, Côte d'Ivoire (1971) 302 p.

Touré et al., 1987 S. Touré, M. Caen-Vachette and P. Tempier, Nouvelles données pétrographiques, géochimiques et géochronologiques du massif 'granitique' de Bondoukou (Côte d'Ivoire) mise en évidence d'un âge Burkinien, par isochrone Rb/Sr sur roches totales, $J$. Afr. Earth Sci. 6 (1987), pp. 269-274.

Van Kranendonk et al., 2004 M.J. Van Kranendonk, W.J. Collins, A. Hickman and M.J. Pawley, Critical tests of vertical vs. Horizontal tectonic models for the Archaean East Pilbara Granite-Greenstone Terrane, Pilbara Craton, Western Australia, Precambrian Res. 131 (3-4) (2004), pp. 173-211.

Vidal, 1987 M. Vidal, Les déformations éburnéennes de l'Unité birimienne de la Comoé (Côte d'Ivoire), J. Afr. Earth Sci. 6 (1987), pp. 141-152.

Vidal and Guibert, 1984 M. Vidal and Ph. Guibert, Un nouveau décrochement ductile nordsud dans le Birimien d'Afrique de l'Ouest: le couloir cisaillant senestre de Wango-Fitini (Côte d'Ivoire), C.R. Acad. Sci. Paris 299 (II) (1984), pp. 1085-1090. 
Vidal et al., 1994 M. Vidal, A and G. lric, The Palaeoproterozoic (Birimian) of Haute-Comoé, in the West African Craton in Côte d'Ivoire: a transtensional back-arc basin, Precambrian Res. 65 (1994), pp. 207-229.

Vidal et al., 1996 M. Vidal, C. Delor, A. Pouclet, Y. Siméon and G. Alric, Evolution géodynamique de l'Afrique de l'Ouest entre 2,2 Ga et 2 Ga: le style “archéen” des ceintures vertes et des ensembles sédimentaires birimiens du nord-est de la Côte-d'Ivoire, Bull. Soc. Géol. Fr. 167 (3) (1996), pp. 307-319.

Yao et al., 1995 B.D. Yao, C. Delor, Y. Siméon, I. Diaby, G. Gadou, P. Kohou, A. Okou, S. Konaté, G. Konan, M. Vidal, A. Cocherie, A. Dommanget, J.P. Cautru and J.C. Chiron, Carte géologique de la Côte-d'Ivoire 1/200000, feuille Dimbokro, Direction des mines et de la géologie, Abidjan, Côte-d'Ivoire (1995).

Yobou, 1993 Yobou, R., 1993. Pétrologie des granitoïdes du protérozoïque inférieur du centre-nord de la Côte-d'Ivoire (Ferkéssédougou-Marabadiassa): Evolution magmatique et contexte géodynamique. Thèse, Univ. de Paris-sud, centre d'Orsay, 309 pp.

Zéade et al., 1995 Z. Zéade, C. Delor, Y. Siméon, B.D. Yao, M. Vidal, Ph. Sonnendrucker, I. Diaby and J.P. Cautru, Carte géologique de la Côte d'Ivoire à 1/200000, feuille de Bondoukou, mémoire $n^{\circ} 10$, Ministère des Mines et de l'Energie, Direction de la Géologie, Abidjan, Côte d'Ivoire (1995). 


\section{Figures}

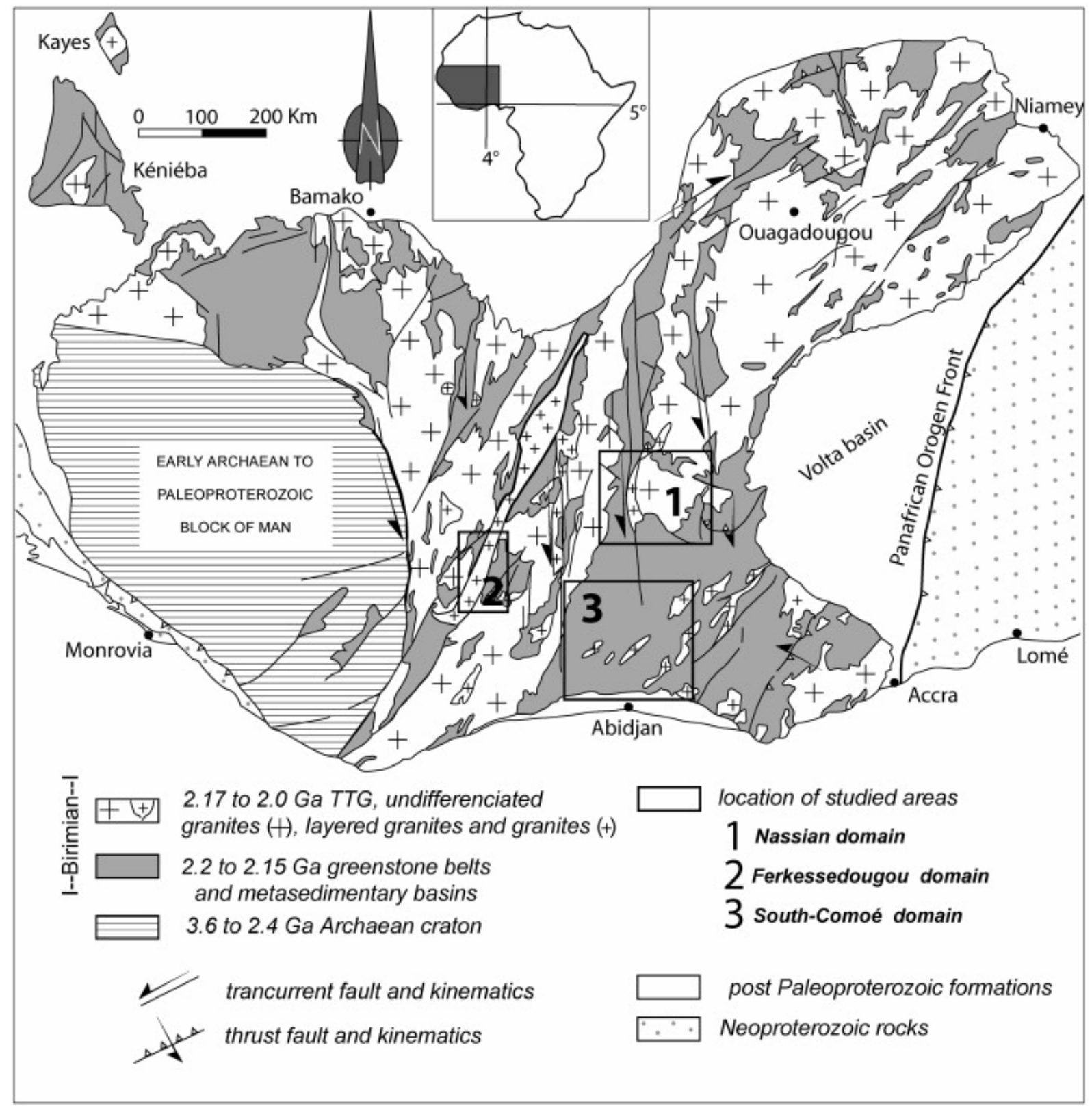

Fig. 1. Simplified geological map of West African Craton (modified after Milési et al., 1989 and Vidal et al., 2006). The Paleoproterozoic domain is located in-between the Archean block of Man, to the west, and the front of the Panafrican orogen, to the east. The three studied domains are represented as black rectangles. 


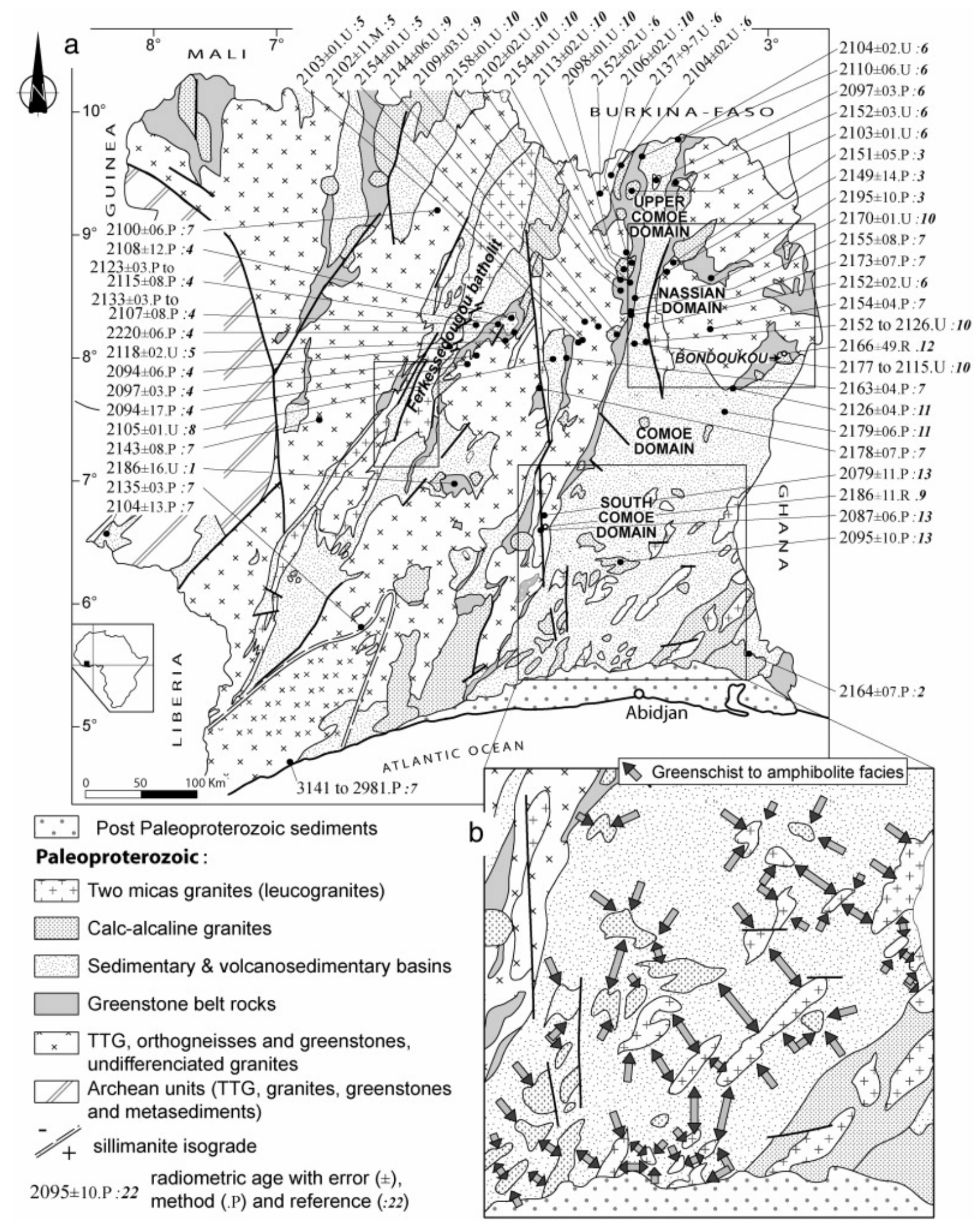

Fig. 2. Compilation of published metamorphic conditions ([Tagini, 1971], [Bard, 1974], [Guibert and Vidal, 1984], [Lemoine, 1988], [Delor et al., 1992a], [Delor et al., 1992b], [Siméon et al. 1995a], [Vidal et al., 1996], [Pouclet et al., 1996], [Doumbia et al., 1998], [Ouattara, 1998] and [Gasquet et al., 2003], Pouclet et al., 2006) and calculated radiometric ages (see details for references below) for Paleoproterozoic rocks. a) Simplified geological map with a compilation of the available ages. Codes for the corresponding radiometric methods are: $\mathrm{U}, \mathrm{U} / \mathrm{Pb}$ conventional ID-TIMS on zircons; $\mathrm{P}, \mathrm{Pb} / \mathrm{Pb}$ on single zircons; $\mathrm{M}, \mathrm{U} / \mathrm{Pb}$ SIMS on zircons and $\mathrm{R}, \mathrm{Rb} / \mathrm{Sr}$ on whole rock. The references corresponding to these ages are 
given at the end of this caption. Black rectangles correspond to the extension of the studies area b) Details of the metamorphic data compilation focused on the South Comoé domain. The compilation shown on this figure displays rather homogeneous and low grade metamorphic conditions at the scale of the entire Paleoproterozoic domain. Note the continuous increase of the metamorphic conditions to the south-western part of the domain. At local scale, metamorphic conditions estimated within the volcano-sedimentary series can increase from greenschist to amphibolite facies, around the plutons, as figured by the arrows. References: 1 - Boher et al., 1992; 2 - [Delor et al., 1992b] and [Delor et al., 1992c]; 3 Delor et al., 1995b; 4 - Doumbia, 1997 and Doumbia et al., 1998; 5 - Gasquet et al., 2003; 6 - Hirdes et al., 1996; 7 - Kouamelan, 1996 and [Kouamelan et al., 1997a] and [Kouamelan et al., 1997b]; 8 - Leake, 1992; 9 - Lemoine, 1988; 10 - [Lüdtke et al., 1992] and [Lüdtke et al., 1998]; 11 - Siméon et al., 1995a; 12 - Touré et al., 1987; 13 - Yao et al., 1995. 

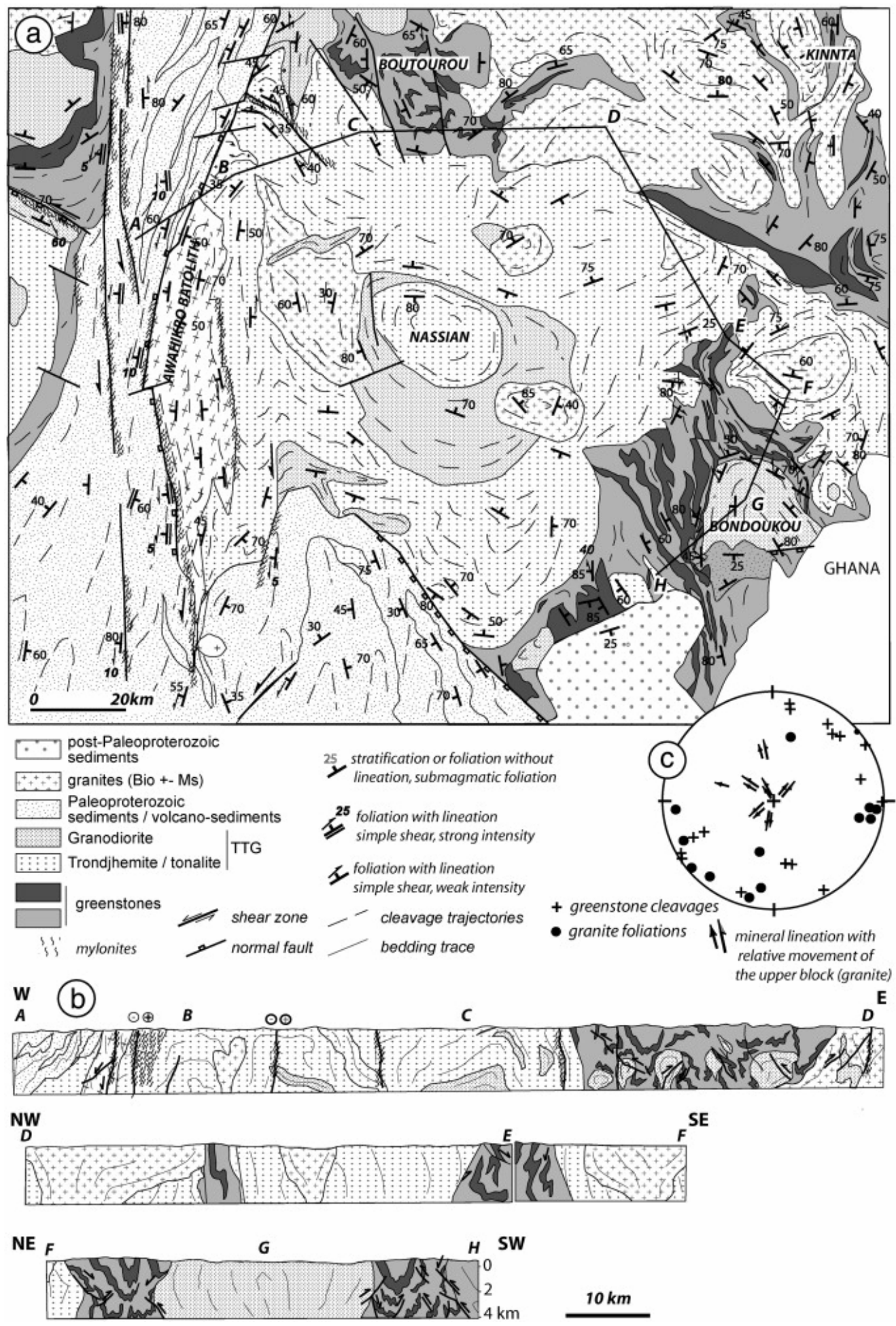

Fig. 3. The Nassian domain: a) Geological and structural map (modified after [Delor et al., 1995b], [Siméon et al., 1995c] and [Zéade et al., 1995]). Within the granitoids, foliation trajectories are figured as thin black lines. b) Cross sections within the Nassian domain. Note that, even if the cross sections present segments with oblique orientations in map view, it shows the same kind of vertical-type structures, and in particular upright folds presenting comparable wavelengths (see location on a). c) Stereographic projection of poles to cleavage within the greenstones, foliation planes and of lineations within the granodiorite measured within and around the Bondoukou massif (Schmidt lower hemisphere projection; see (a) for location). Kinematic criteria observed within the pluton are also shown. 


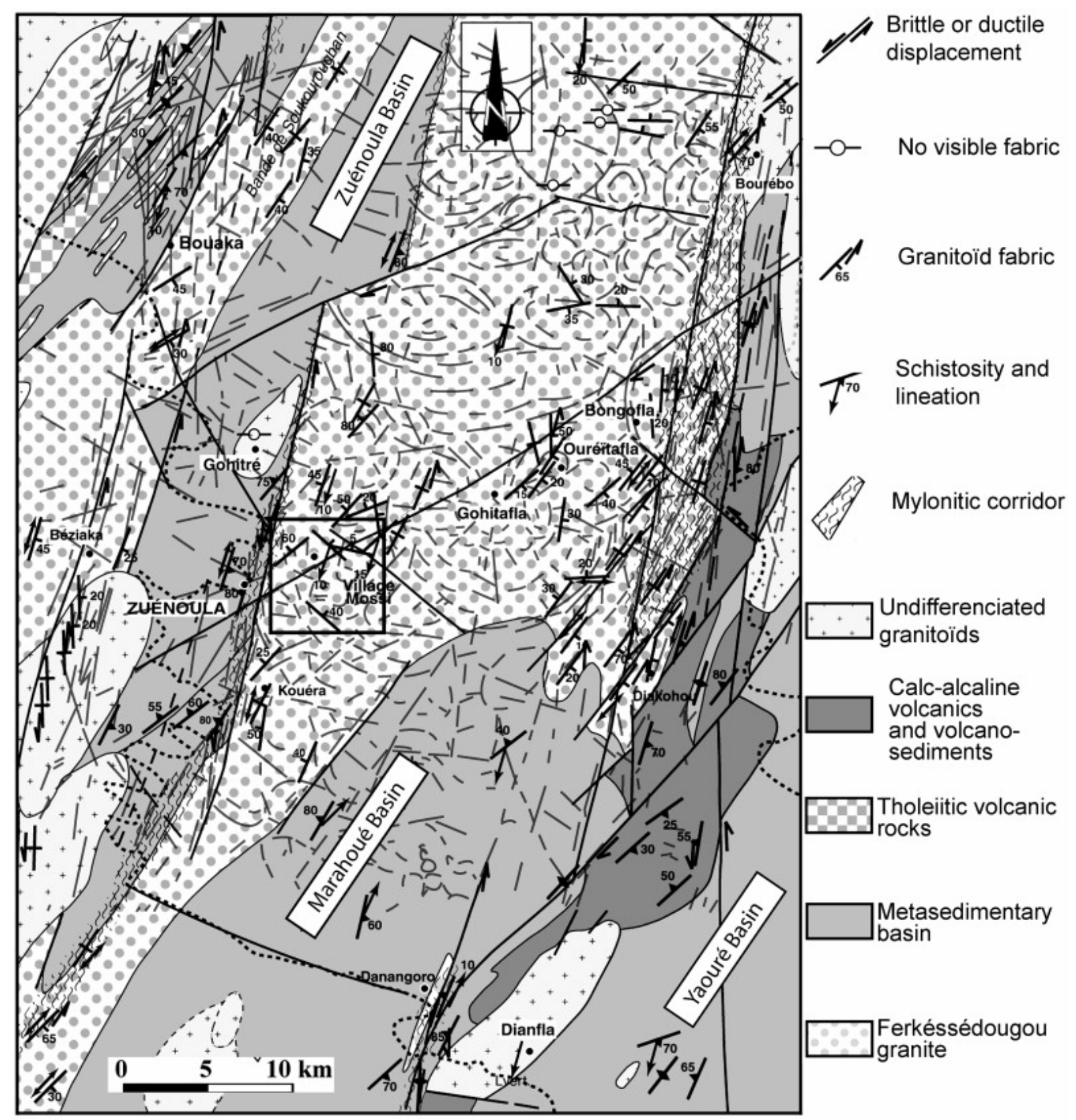

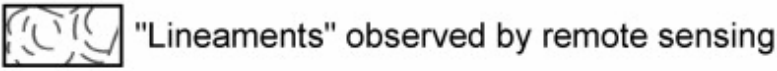

location of Fig. 6

Fig. 4. Geological and structural map of the Ferkessedougou domain. In map view, the Ferkessedougou leucogranite presents different apophysis sometimes limited by strike-slip ductile shear zones. Within the core of the massif, the granite displays an alternation of zones with rather intense deformation and zones with hardly visible one. Location of the map of Fig. 6 is shown here. 

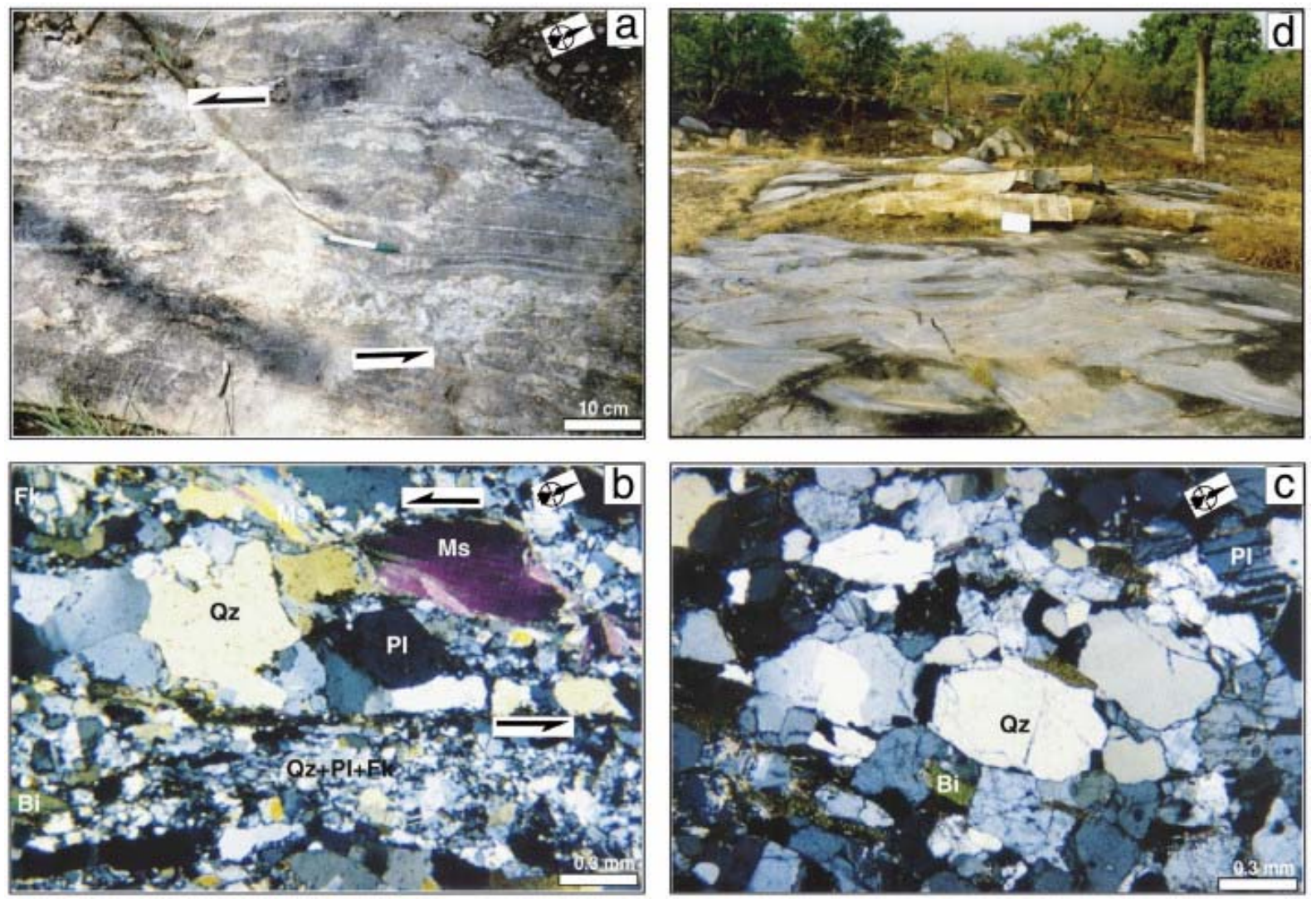

Fig. 5. Photographs of structures observed within the Ferkessedougou granite: a) sinistral simple-shear structure observed in a horizontal plane, b) photograph of a thin section, in a sample from a rather intensely deformed zone of the granite, showing sinistral simple shearing, c) photograph of a thin section, in a sample from a poorly deformed zone of the granite, showing sub-magmatic fabric with cryptic preferred orientations, d) sub-horizontal fabric, marked by jointing planes, on top of one of the plutons forming the Ferkessedougou massif. 
a
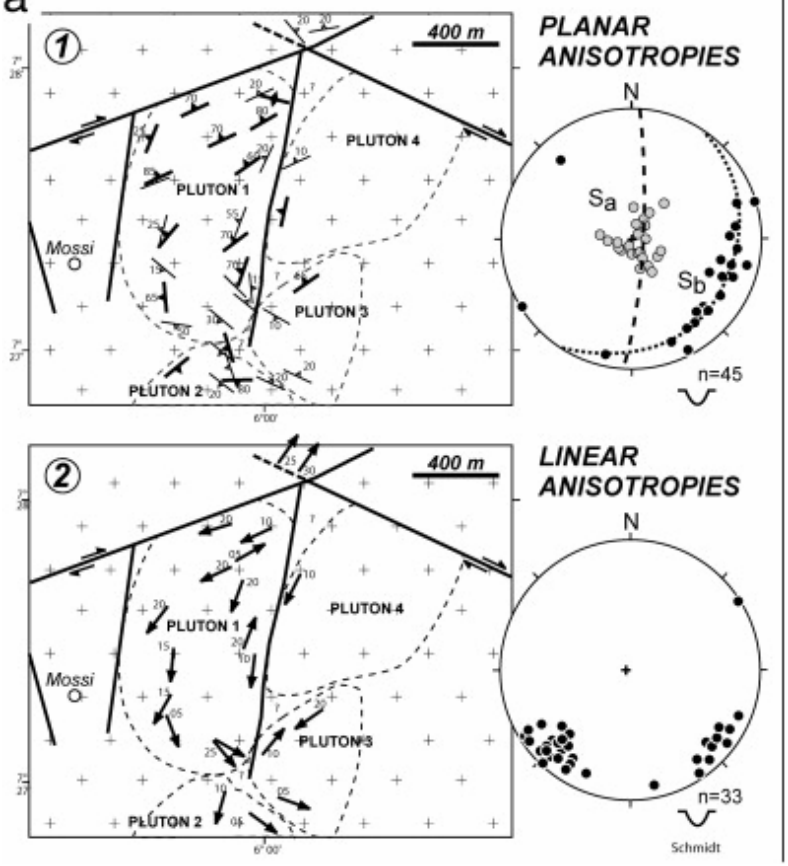

b
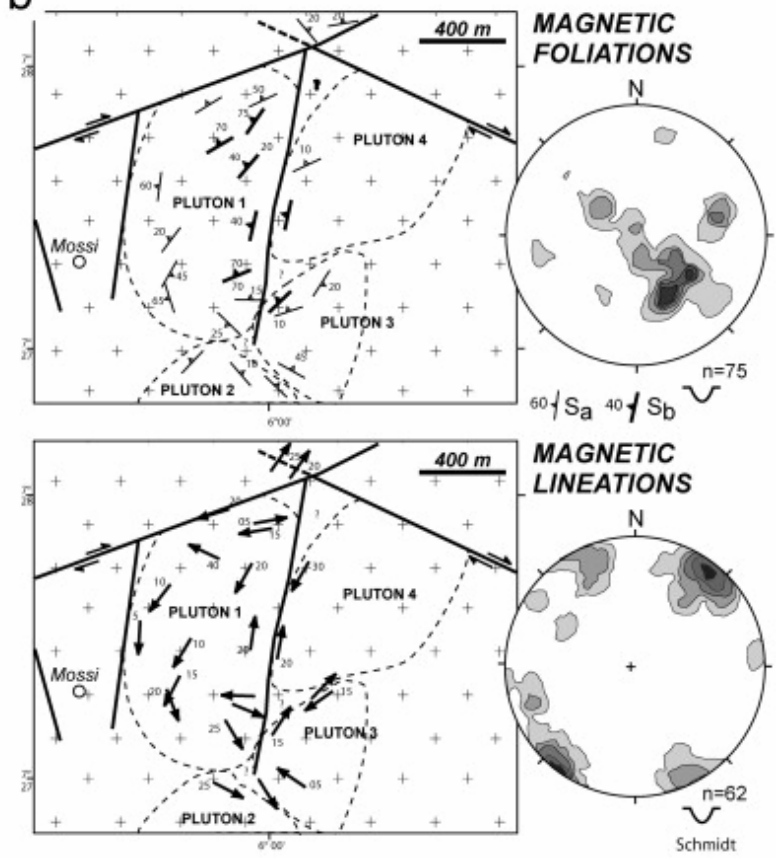

Fig. 6. Structural analysis of a poorly deformed zone within the Ferkessedougou leucogranite (see location on Fig. 4). a) Structural map and stereoplot for planar (1) and linear (2) anisotropies mainly deduced from Fe-Mg minerals alignment analysis within the granite. Two orientation families are visible for planar anisotropies, a sub-horizontal one and one striking NNE to NE, steeply dipping to the NW. Two orientation families are also observed for sub-horizontal linear anisotropies, one striking SW, parallel to the cartographic orientation of the Ferkessedougou massif, and one striking SE. Faults and plutons' boundaries have been deduced from lineaments interpretation using remote sensing analysis (SPOT-XS images). b) Magnetic fabric obtained by Ouattara (1998) in the same study area. Orientations of the magnetic foliations and lineations confirm the ones observed on the field (compare (a) and (b)). 

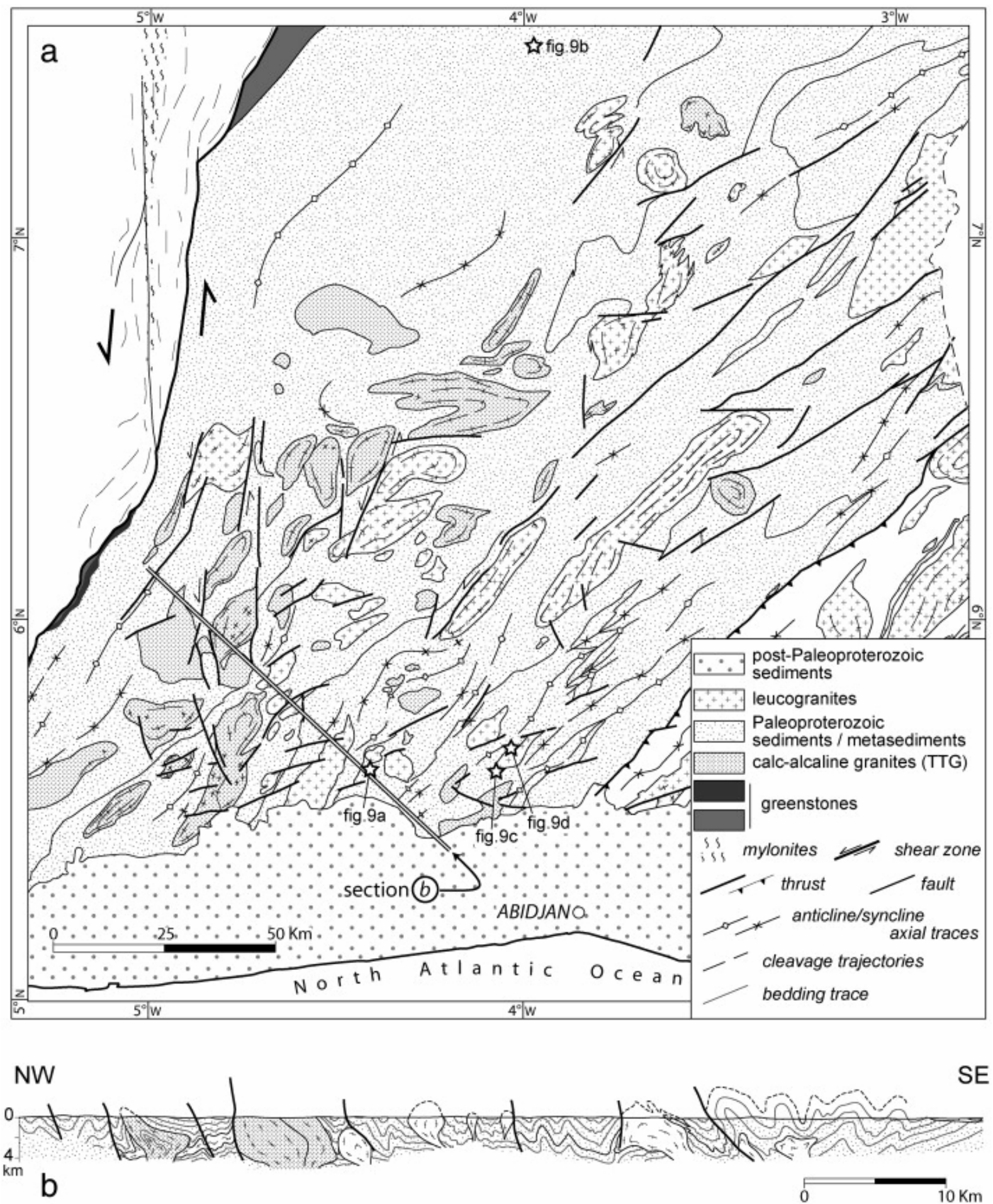

Fig. 7. Structural analysis of the South Comoé domain. a) Geological and structural map (modified after [Delor et al., 1992c], [Siméon et al., 1992], [Siméon et al., 1995c], [Adou et al., 1995] and [Yao et al., 1995]). Note that the fold axes within the volcano-sedimentary series strike almost parallel to the elongated cartographic shape of the granites. Locations of the photographs on Fig. 9 are shown by the four stars. b) NW-SE oriented regional-scale cross section within the South Comoé domain (see location on (a)). 

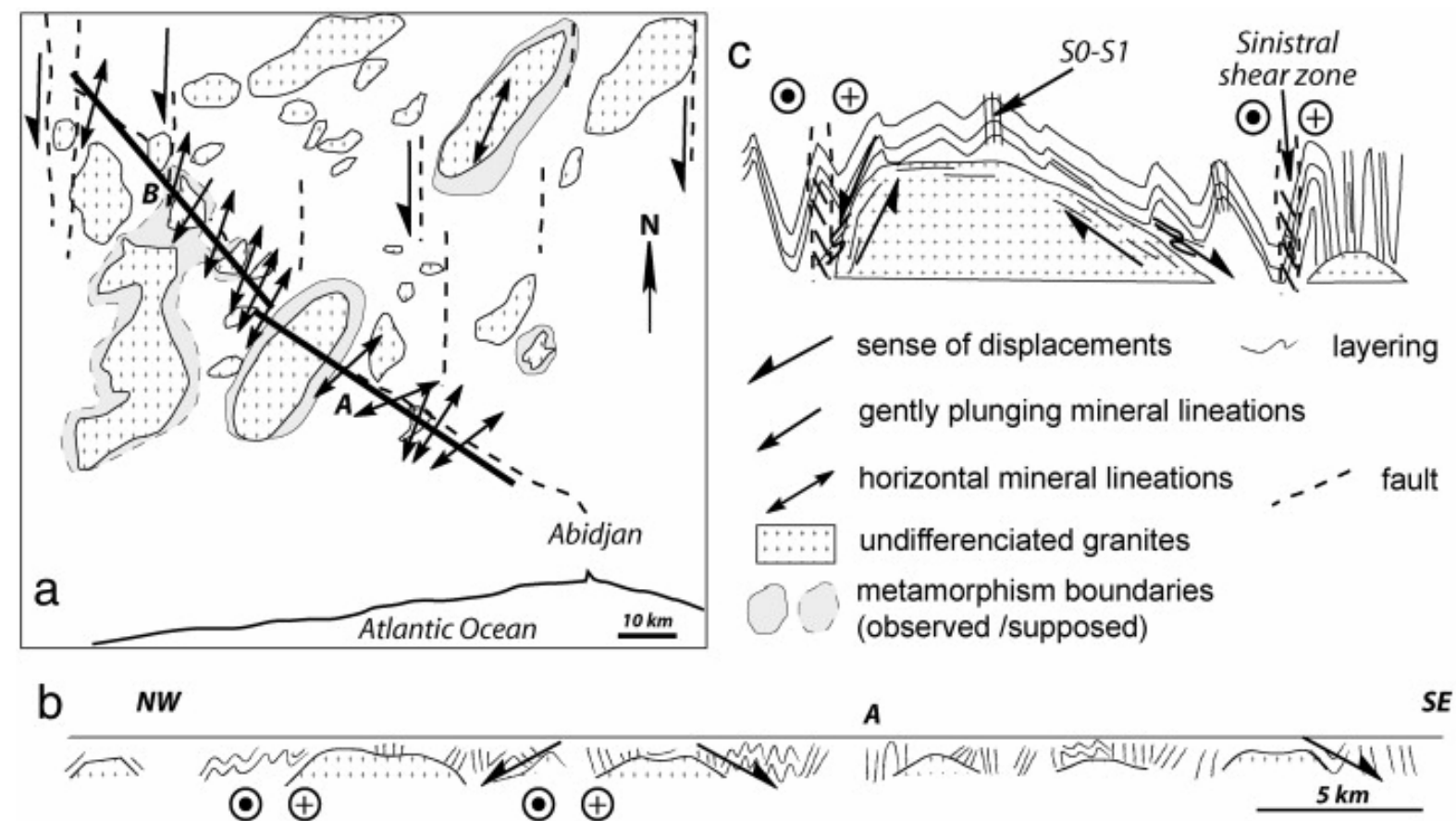

$\odot \oplus$

$\odot \oplus$

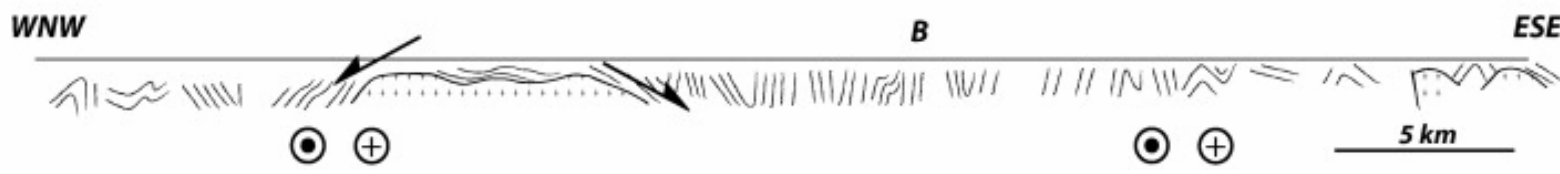

Fig. 8. Detailed field structural observations along a NW oriented section located NW of Abidjan, within the South Comoé domain. a) Geological sketch map with i) contacts between granites and volcano-sedimentary rocks, ii) location of the metamorphic zones, observed and supposed, around the plutons and iii) structural measurements, including faults, mineral lineation orientations and kinematic shear criteria. b) Cross section showing the deformation pattern within the volcano-sedimentary series and the relationships between the granites and their surrounding rocks. c) Summary sketch of the structures observed along the section including: i) upright folding of the volcano-sedimentary series, with development of cleavage, parallel to the axial planes, ii) more gently folding of some layers located directly on top of the granites, iii) sinistral shear zones located along some of the plutons and iv) normal-type movements along the external boundaries of the plutons. 

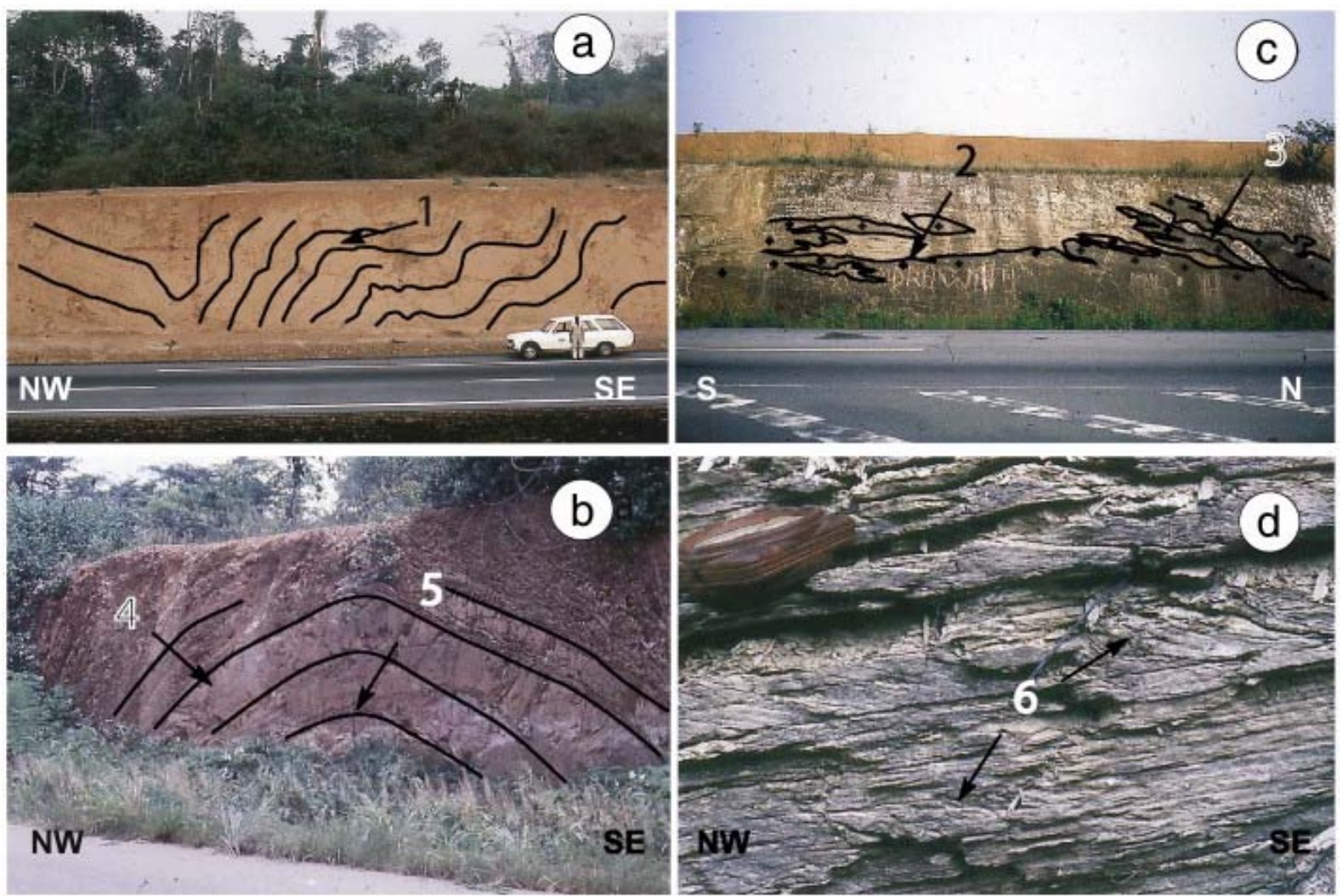

Fig. 9. Photographs of outcrops within the South Comoé domain (see locations on Fig. 7). a) upright folds (1) developed within the sedimentary series of the Comoé basin, far from the granites. b) upright fold (4), with the development of a cleavage parallel to the axial plane (5), within the sedimentary layers. c) gently folded to sub-horizontal volcano-sedimentary series on top of a granite (2) with granite apophysis (3). d) shallowly dipping shear bands (6) showing normal-type movement into the volcano-sedimentary series, close to the contact with a pluton. 


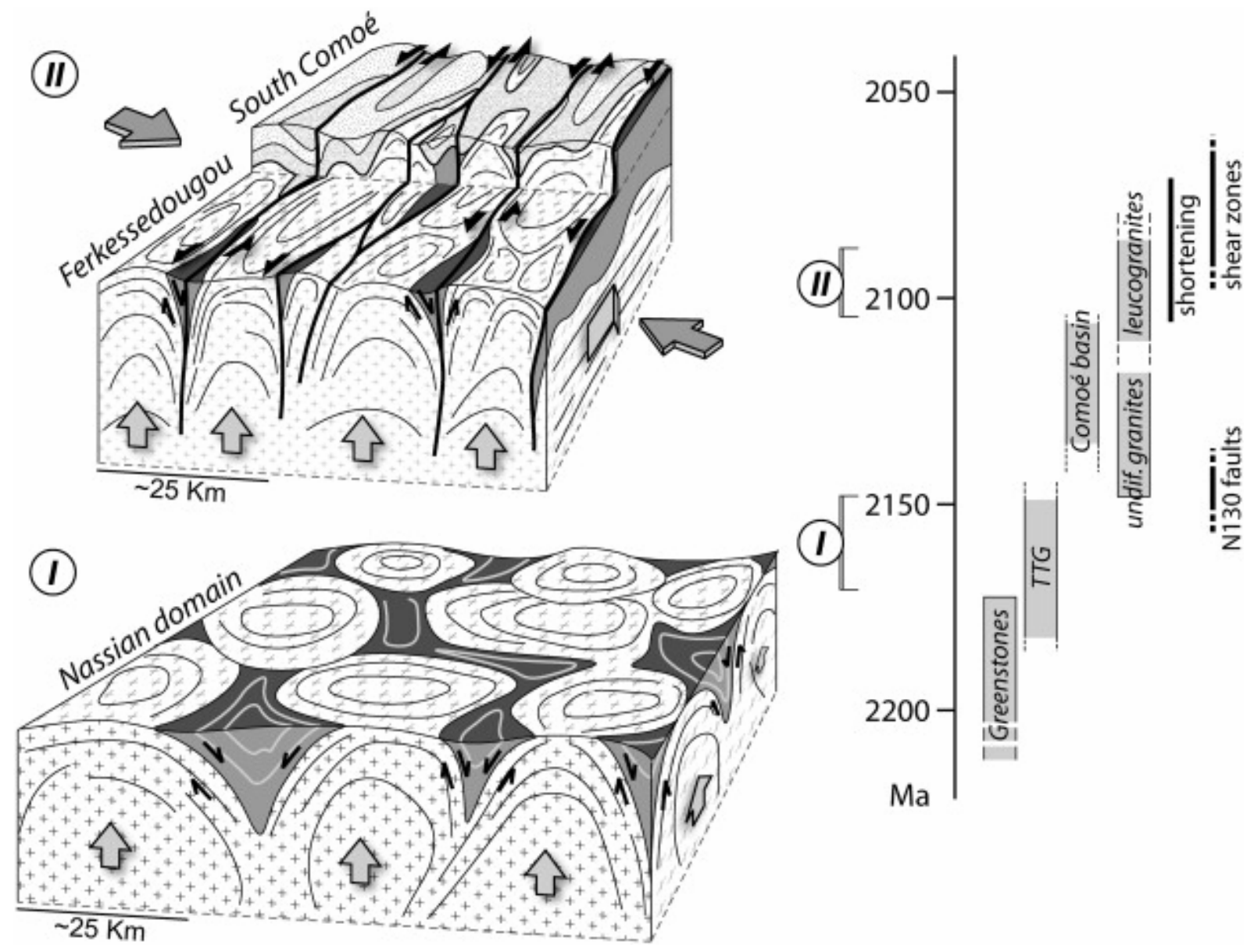

Fig. 10. 3d sketch illustrating the drawing of the two folds evolution history of the Eburnean orogeny within the Paleoproterozoic domain of Ivory Coast. (I) Basins and domes type structure resulting from the diapiric uprising of the TTG units and the relative burial of the greenstones (Nassian domain). Cross drawing pattern corresponds to TTG rocks, with circular foliation trajectories figured as thin black lines. Greenstone belts are represented with dark grey, with layering figured as white lines. (II) Coeval vertical movements and horizontal, regional-scale shortening corresponding to the deformation pattern observed within the South Comoé domain and the Ferkessedougou domain, which displays a deeper erosion level within the crust. The resulting structures consist in i) upright folds developed within the volcanosedimentary series (dots drawing pattern), ii) tight plutons elongated at high angle with the maximum horizontal shortening direction (cross pattern), iii) normal-type movements and a turn up of the surrounding units along the syn-kinematics plutons' boundaries and iv) development of ductile strike-slip shear zones along some of the plutons' boundaries. 